\title{
Anionic Fluorinated Zn-porphyrin Combined with Cationic Endohedral Li-Fullerene for Long-Lived Photoinduced Charge Separation with Low Energy Loss
}

Kazuhira Miwa, ${ }^{\dagger}$ Shinobu Aoyagi, ${ }^{*}{ }^{\dagger}$ Takahiro Sasamori, ${ }^{\wedge}$ Hiroshi Ueno, ${ }^{\ddagger}{ }^{\dagger}$ Hiroshi Okada, ${ }^{\S, 1, \perp}$ and Kei Ohkubo $^{\#}$

${ }^{\dagger}$ Department of Information and Basic Science, Nagoya City University, Nagoya, 467-8501, Japan

'Division of Chemistry, Faculty of Pure and Applied Sciences, and Tsukuba Research Center for Energy Materials Sciences (TREMS), University of Tsukuba, Tsukuba, 305-8571, Japan

Creative Interdisciplinary Research Division, Frontier Research Institute for Interdisciplinary Sciences (FRIS), Tohoku University, Sendai 980-8578, Japan

IIDepartment of Chemistry, Graduate School of Science, Tohoku University, Sendai, 980-8578, Japan

${ }^{\S}$ Fukamatsugumi Co., Ltd. Sendai, 981-0931, Japan

Idea International Co., Ltd. Sendai, 981-0922, Japan

${ }^{\perp}$ Center for Fundamental and Applied Research of Novel Nanocarbon Derivatives, Center for Key Interdisciplinary Research, Tohoku University, Sendai, 980-8578, Japan

${ }^{\#}$ Institute for Advanced Co-Creation Studies, Open and Transdisciplinary Research Initiatives, Osaka University, Suita, 565-0871, Japan

*E-mail: aoyagi@nsc.nagoya-cu.ac.jp

Contents

1. Materials and instrumentation

2. Synthesis and NMR spectra of $\mathrm{ZnTF}_{5} \mathrm{PP}, \mathrm{ZnTF}_{4} \mathrm{PPTC}^{4-} 4 \mathrm{TBA}^{+}, \mathrm{ZnTPPS} \mathrm{ZnTPPS}^{4-} 4 \mathrm{TBA}^{+}, \mathrm{H}_{2} \mathrm{TF}_{4} \mathrm{PP}$, $\mathrm{ZnTF}_{4} \mathrm{PP}, \mathrm{H}_{2} \mathrm{TF}_{2} \mathrm{PP}, \mathrm{ZnTF}_{2} \mathrm{PP}$, and $\mathrm{TBA}^{+} \mathrm{TFSI}^{-}$

3. $\mathrm{CV}$ and DPV curves of $\mathrm{H}_{2} \mathrm{TF}_{2} \mathrm{PP}$ and $\mathrm{H}_{2} \mathrm{TF}_{4} \mathrm{PP}$

4. X-ray structure analysis of $\mathrm{H}_{2} \mathrm{TF}_{4} \mathrm{PP}$ and $\left(\mathrm{H}_{2} \mathrm{TF}_{4} \mathrm{PP}\right)_{3}\left(\mathrm{Li}^{+} @ \mathrm{C}_{60} \mathrm{TFSI}\right)_{2}$

References 


\section{Materials and instrumentation}

The starting materials were purchased from commercial sources and used without further purification. ${ }^{1} \mathrm{H}$

and ${ }^{19}$ F NMR spectra were recorded on a JEOL JNM-ECZ500R spectrometer at $500 \mathrm{MHz}$. UV-vis absorption spectra were recorded on a SHIMADZU UV-1700 spectrometer. Fluorescence and phosphorescence emission spectra were recorded on SHIMADZU RF-5300PC and HORIBA FluoroMax-4 spectrometers, respectively. CV and DPV curves were recorded on a BAS ALS842D electrochemical analyzer with a three-electrode cell. Single crystal X-ray diffraction data were recorded on a DECTRIS PILATUS3 X CdTe $1 \mathrm{M}$ detector at beamline BL02B1 of the SPring-8 large synchrotron radiation facility. Time-resolved transient absorption spectra were recorded on a UNISOKU laser flash photolysis system.

\section{Synthesis and NMR spectra of $\mathrm{ZnTF}_{5} \mathrm{PP}, \mathrm{ZnTF}_{4} \mathrm{PPTC}^{4-}{ }^{4} \mathrm{TBA}^{+}, \mathrm{ZnTPPS}, \mathrm{ZnTPPS}^{4-} \mathbf{4 T B A}^{+}$, $\mathrm{H}_{2} \mathrm{TF}_{4} \mathrm{PP}, \mathrm{ZnTF}_{4} \mathrm{PP}, \mathrm{H}_{2} \mathrm{TF}_{2} \mathrm{PP}, \mathrm{ZnTF}_{2} \mathrm{PP}$, and $\mathrm{TBA}^{+} \mathrm{TFSI}^{-}$}

$\mathrm{ZnTF}_{5} \mathrm{PP}$ was synthesized from commercial $\mathrm{H}_{2} \mathrm{TF}_{5} \mathrm{PP}$ according to a published method (Scheme 1). ${ }^{1}$ In a $25 \mathrm{~mL}$ round-bottom flask equipped with a Dimroth condenser and a magnetic stirrer, $\mathrm{H}_{2} \mathrm{TF}_{5} \mathrm{PP}(10.0 \mathrm{mg}, 10.0$ $\mu \mathrm{mol})$ and zinc acetate $\left(\mathrm{Zn}(\mathrm{OAc})_{2}\right)(25.0 \mathrm{mg}, 0.140 \mathrm{mmol})$ were dissolved in a methanol/chloroform mixed solvent $(1: 1 \mathrm{v} / \mathrm{v}, 3 \mathrm{~mL})$. The brown mixture was stirred at reflux under argon atmosphere for 5 hours. After the mixture was cooled to room temperature, the solvent was evaporated, and the crude material was purified by silica gel column chromatography (eluent: hexane/chloroform, 1:1 v/v) to obtain $\mathrm{ZnTF}_{5} \mathrm{PP}(10.2 \mathrm{mg}, 9.6 \mu \mathrm{mol}$, $96 \%$ ) as a magenta solid. ${ }^{1} \mathrm{H} \mathrm{NMR}\left(500 \mathrm{MHz}, \mathrm{CDCl}_{3}\right.$, TMS as internal reference): $\delta 8.93$ (s, $8 \mathrm{H}, \beta$-H) (Figure S1a). ${ }^{19} \mathrm{~F}$ NMR (500 MHz, $\mathrm{CDCl}_{3}, \mathrm{C}_{6} \mathrm{~F}_{6}$ as external reference): $\delta-137.96$ (q, 8F, ortho-F), -153.04 (t, 4F, para-F), -162.86 (m, 8F, meta-F) (Figure $\mathrm{S} 1 \mathrm{~b})$.

$\mathrm{ZnTF}_{4} \mathrm{PPTC}^{4-} 4 \mathrm{TBA}^{+}$was synthesized from $\mathrm{ZnTF}_{5} \mathrm{PP}$ by simultaneous nucleophilic substitution with thioglycolic acid ${ }^{2}$ and deprotonation in the presence of $\mathrm{TBA}^{+} \mathrm{OH}^{-}$(Scheme 1). In a $25 \mathrm{~mL}$ round-bottom flask equipped with a magnetic stirrer, $\mathrm{ZnTF}_{5} \mathrm{PP}(32.6 \mathrm{mg}, 31.0 \mu \mathrm{mol})$ and thioglycolic acid $(8.5 \mu \mathrm{L}, 0.122 \mathrm{mmol})$ were dissolved in DMF $(1 \mathrm{~mL})$. The magenta solution was added to $10 \% \mathrm{TBA}^{+} \mathrm{OH}^{-}$methanol solution $(800$ $\mu \mathrm{L}, 0.244 \mathrm{mmol}$ ) and then stirred at $50^{\circ} \mathrm{C}$ under argon atmosphere for 2 hours. After the mixture was cooled to room temperature, the solvent was evaporated, and the crude material was purified by Sephadex LH20 column chromatography (eluent: methanol) to obtain $\mathrm{ZnTF}_{4} \mathrm{PPTC}^{4-} 4 \mathrm{TBA}^{+}(61.8 \mathrm{mg}, 27.0 \mu \mathrm{mol}, 87 \%)$ as a magenta solid. ${ }^{1} \mathrm{H}$ NMR (500 MHz, $\left.\mathrm{CD}_{3} \mathrm{OD}\right): \delta 9.11(\mathrm{~s}, 8 \mathrm{H}, \beta-\mathrm{H}), 3.99\left(\mathrm{~s}, 8 \mathrm{H}, \mathrm{S}_{-} \mathrm{CH}_{2}\right), 3.04\left(\mathrm{~m}, 32 \mathrm{H}, \mathrm{N}_{-} \mathrm{CH}_{2}\right), 1.50(\mathrm{~m}$, $32 \mathrm{H}, \mathrm{CH}_{2}$ ), $1.29\left(\mathrm{~m}, 32 \mathrm{H}, \mathrm{CH}_{2}\right), 0.95\left(\mathrm{t}, 48 \mathrm{H}, \mathrm{CH}_{3}\right.$ ) (Figure $\left.\mathrm{S} 2 \mathrm{a}\right) .{ }^{19} \mathrm{~F}$ NMR $\left(500 \mathrm{MHz}, \mathrm{CD}_{3} \mathrm{OD}, \mathrm{C}_{6} \mathrm{~F}_{6}\right.$ as internal reference): $\delta-134.65$ (q, 8F, ortho-F), -138.18 (q, 8F, meta-F) (Figure S2b).

ZnTPPS was synthesized from commercial $\mathrm{H}_{2}$ TPPS according to a published method (Scheme S1). ${ }^{3}$ In a $25 \mathrm{~mL}$ round-bottom flask equipped with a magnetic stirrer, $\mathrm{H}_{2} \mathrm{TPPS}(34.2 \mathrm{mg}, 37.0 \mu \mathrm{mol})$ and $\mathrm{ZnSO}_{4} \cdot 7 \mathrm{H}_{2} \mathrm{O}$ (30.4 mg, $0.106 \mathrm{mmol}$ ) were dissolved in DMF $(1 \mathrm{~mL})$ and heated to reflux for 6 hours with monitoring by UV-vis absorption spectroscopy. After cooled to room temperature, excess acetone was added, and the reaction mixture was placed in the refrigerator for 1 day. The resulting precipitate was filtered and washed with water, and then purified by Sephadex LH20 column chromatography (eluent: methanol) to obtain 
ZnTPPS (26.9 mg, $27.0 \mu \mathrm{mol}, 73 \%)$ as a purple solid. ${ }^{1} \mathrm{H}$ NMR (500 MHz, DMSO- $\left.d_{6}\right): \delta 8.78$ (s, 8H, $\beta$-H), $8.12(\mathrm{~m}, 8 \mathrm{H}$, meta-H), 8.01 (m, 8H, ortho-H) (Figure $\mathrm{S} 3$ ).

$\mathrm{ZnTPPS}^{4-} 4 \mathrm{TBA}^{+}$was synthesized from ZnTPPS by deprotonation with $\mathrm{TBA}^{+} \mathrm{OH}^{-}$(Scheme S1). In a 25 $\mathrm{mL}$ round-bottom flask equipped with a magnetic stirrer, ZnTPPS $(8.8 \mathrm{mg}, 8.8 \mu \mathrm{mol})$ was dissolved in methanol. $10 \% \mathrm{TBA}^{+} \mathrm{OH}^{-}$methanol solution $(110 \mu \mathrm{L}, 34.0 \mu \mathrm{mol})$ was injected into the solution and stirred at room temperature for $20 \mathrm{~min}$. The reaction mixture was purified by Sephadex LH20 column chromatography (eluent: methanol) to obtain $\mathrm{ZnTPPS}^{4-}{ }^{4 \mathrm{TBA}^{+}}(17.0 \mathrm{mg}, 8.7 \mu \mathrm{mol}, 99 \%)$ as a purple solid. ${ }^{1} \mathrm{H}$ NMR (500 MHz, $\left.\mathrm{CD}_{3} \mathrm{OD}\right): \delta 8.86(\mathrm{~s}, 8 \mathrm{H}, \beta-\mathrm{H}), 8.27(\mathrm{~m}, 16 \mathrm{H}, \mathrm{Ph}-\mathrm{H}), 3.16\left(\mathrm{~m}, 32 \mathrm{H}, \mathrm{N}-\mathrm{CH}_{2}\right), 1.59\left(\mathrm{~m}, 32 \mathrm{H}, \mathrm{CH}_{2}\right), 1.37(\mathrm{~m}, 32 \mathrm{H}$, $\left.\mathrm{CH}_{2}\right), 0.99\left(\mathrm{t}, 48 \mathrm{H}, \mathrm{CH}_{3}\right)$ (Figure $\mathrm{S} 4$ ).

$\mathrm{H}_{2} \mathrm{TF}_{4} \mathrm{PP}$ was synthesized according to a published method (Scheme $\mathrm{S} 2$ ). ${ }^{4}$ In a $25 \mathrm{~mL}$ round-bottom flask equipped with a Dimroth condenser and a magnetic stirrer, 2,3,5,6-tetrafluorobenzaldehyde $(0.20 \mathrm{~mL}, 1.7$ $\mathrm{mmol})$, distilled pyrrole $(0.12 \mathrm{~mL}, 1.7 \mathrm{mmol})$ and boron trifluoride diethyl ether complex $\left(\mathrm{BF}_{3} \cdot \mathrm{OEt}_{2}\right)(0.20$ $\mathrm{mL}, 1.6 \mathrm{mmol})$ were dissolved in degassed dichloromethane $(30 \mathrm{~mL})$ and stirred at room temperature under argon atmosphere. After 1 hour, 2,3-dichloro-5,6-dicyano-p-benzoquinone (DDQ) (1.5 g, $6.6 \mathrm{mmol}$ ) was added, and then stirred for 24 hours. After reaction mixture was evaporated to dryness, the resulting solid was purified by silica gel flash column chromatography (eluent: hexane/chloroform, $1: 1 \mathrm{v} / \mathrm{v}$ ) to obtain $\mathrm{H}_{2} \mathrm{TF}_{4} \mathrm{PP}$ (87.3 mg, $0.097 \mathrm{mmol}, 24 \%$ ) as a purple solid. ${ }^{1} \mathrm{H}$ NMR (500 MHz, $\mathrm{CDCl}_{3}$, TMS as internal reference): $\delta 8.85$ $(\mathrm{s}, 8 \mathrm{H}, \beta-\mathrm{H}), 7.56(\mathrm{~m}, 4 \mathrm{H}$, para- $\mathrm{H}), 2.94(\mathrm{~s}, 2 \mathrm{H}, \mathrm{N}-\mathrm{H})$ (Figure $\mathrm{S} 5 \mathrm{a}) .{ }^{19} \mathrm{~F}$ NMR $\left(500 \mathrm{MHz}, \mathrm{CDCl}_{3}, \mathrm{C}_{6} \mathrm{~F}_{6}\right.$ as internal reference): $\delta-138.42$ (m, 8F, ortho-F), $-139.76(\mathrm{~m}, 8 \mathrm{~F}$, meta-F) (Figure S5b).

$\mathrm{ZnTF}_{4} \mathrm{PP}$ was synthesized from $\mathrm{H}_{2} \mathrm{TF}_{4} \mathrm{PP}$ according to a published method (Scheme S2). ${ }^{5}$ In a $25 \mathrm{~mL}$ round-bottom flask equipped with a Dimroth condenser and a magnetic stirrer, $\mathrm{H}_{2} \mathrm{TF}_{4} \mathrm{PP}(5.0 \mathrm{mg}, 5.5 \mu \mathrm{mol})$ and $\mathrm{Zn}(\mathrm{OAc})_{2}(3.0 \mathrm{mg}, 0.016 \mathrm{mmol})$ were dissolved in DMF $(1 \mathrm{~mL})$ and heated to reflux for 3 hours under argon atmosphere. After the mixture was cooled to room temperature, the solvent was evaporated, and the crude material was purified by silica gel column chromatography (eluent: hexane/chloroform, 1:1 v/v) to obtain $\mathrm{ZnTF}_{4} \mathrm{PP}(1.94 \mathrm{mg}, 2.0 \mu \mathrm{mol}, 36 \%)$ as a magenta solid. ${ }^{1} \mathrm{H} \mathrm{NMR}\left(500 \mathrm{MHz}, \mathrm{CDCl}_{3}\right.$, TMS as internal reference): $\delta 8.92(\mathrm{~s}, 8 \mathrm{H}, \beta-\mathrm{H}), 7.56(\mathrm{~m}, 4 \mathrm{H}$, para-H) (Figure $\mathrm{S} 6 \mathrm{a}) .{ }^{19} \mathrm{~F} \mathrm{NMR}\left(500 \mathrm{MHz}, \mathrm{CDCl}_{3}, \mathrm{C}_{6} \mathrm{~F}_{6}\right.$ as internal reference): $\delta-138.70(\mathrm{~m}, 8 \mathrm{~F}$, ortho-F), $-140.13(\mathrm{~m}, 8 \mathrm{~F}$, meta-F) (Figure $\mathrm{S} 6 \mathrm{~b})$.

$\mathrm{H}_{2} \mathrm{TF}_{2} \mathrm{PP}$ was synthesized according to a published method (Scheme S3). ${ }^{6} \mathrm{In}$ a $200 \mathrm{~mL}$ round-bottom flask equipped with a Dimroth condenser and a magnetic stirrer, 2,6-difluorobenzaldehyde (3.0 mL, $0.028 \mathrm{~mol})$ and distilled pyrrole $(1.9 \mathrm{~mL}, 0.027 \mathrm{~mol})$ were dissolved in propionic acid $(100 \mathrm{~mL})$ and heated to reflux for 1 hour. After cooled to room temperature, the reaction mixture was filtered and washed with hot water and methanol. The resulting solid was dried in vacuo to obtain $\mathrm{H}_{2} \mathrm{TF}_{2} \mathrm{PP}(668 \mathrm{mg}, 0.88 \mathrm{mmol}, 13 \%)$ as a purple solid. ${ }^{1} \mathrm{H}$ NMR (500 MHz, $\mathrm{CDCl}_{3}$, TMS as internal reference): $\delta 8.80(\mathrm{~s}, 8 \mathrm{H}, \beta-\mathrm{H}), 7.73(\mathrm{~m}, 4 \mathrm{H}$, para-H), 7.32 $\left(\mathrm{m}, 8 \mathrm{H}\right.$, meta-H) (Figure S7a). ${ }^{19} \mathrm{~F}$ NMR $\left(500 \mathrm{MHz}, \mathrm{CDCl}_{3}, \mathrm{C}_{6} \mathrm{~F}_{6}\right.$ as internal reference): $\delta-109.38$ (m, 8F, ortho-F) (Figure S7b).

$\mathrm{ZnTF}_{2} \mathrm{PP}$ was synthesized from $\mathrm{H}_{2} \mathrm{TF}_{2} \mathrm{PP}$ according to a published method (Scheme S3). ${ }^{5}$ In a $25 \mathrm{~mL}$ round-bottom flask equipped with a Dimroth condenser and a magnetic stirrer, $\mathrm{H}_{2} \mathrm{TF}_{2} \mathrm{PP}(10.0 \mathrm{mg}, 13.0 \mu \mathrm{mol})$ and $\mathrm{Zn}(\mathrm{OAc})_{2}(7.2 \mathrm{mg}, 0.039 \mathrm{mmol})$ were dissolved in DMF $(1 \mathrm{~mL})$ and heated to reflux for 3 hours. After 
the mixture was cooled to room temperature, the solvent was evaporated, and the crude material was purified by silica gel column chromatography (eluent: hexane/chloroform, 1:1 v/v) to obtain $\mathrm{ZnTF}_{2} \mathrm{PP}(8.6 \mathrm{mg}, 10.5$ $\mu \mathrm{mol}, 81 \%)$ as a magenta solid. ${ }^{1} \mathrm{H}$ NMR $\left(500 \mathrm{MHz}, \mathrm{CDCl}_{3}\right.$, TMS as internal reference): $\delta 8.95(\mathrm{~s}, 8 \mathrm{H}, \beta$-H), $7.79(\mathrm{~m}, 4 \mathrm{H}$, para- $\mathrm{H}), 7.37\left(\mathrm{~m}, 8 \mathrm{H}\right.$, meta-H) (Figure S8a). ${ }^{19} \mathrm{~F} \mathrm{NMR}\left(500 \mathrm{MHz}, \mathrm{CDCl}_{3}, \mathrm{C}_{6} \mathrm{~F}_{6}\right.$ as internal reference): $\delta-109.61$ (s, 8F, ortho-F) (Figure $\mathrm{S} 8 \mathrm{~b}$ ).

$\mathrm{TBA}^{+} \mathrm{TFSI}^{-}$was synthesized from $\mathrm{TBA}^{+} \mathrm{Br}^{-}$and $\mathrm{Li}^{+} \mathrm{TFSI}^{-}$according to a published method (Scheme S4). ${ }^{7}$ In a $100 \mathrm{~mL}$ round-bottom flask equipped with a magnetic stirrer, aqueous solution $(30 \mathrm{~mL})$ of $\mathrm{TBA}^{+} \mathrm{Br}^{-}(7.02$ g, $0.022 \mathrm{mmol}$ ) was slowly added to aqueous solution $(5 \mathrm{~mL})$ of $\mathrm{Li}^{+}{ }^{+} \mathrm{TFSI}^{-}(6.95 \mathrm{~g}, 0.024 \mathrm{mmol})$. The mixture was stirred at room temperature for 2 hours. The resulting precipitate was filtered and washed with water, and then dried to obtain $\mathrm{TBA}^{+} \mathrm{TFSI}^{-}(9.83 \mathrm{~g}, 0.019 \mathrm{mmol}, 86 \%)$ as a white solid. ${ }^{1} \mathrm{H} \mathrm{NMR}\left(500 \mathrm{MHz}, \mathrm{CDCl}_{3}\right.$, TMS as internal reference): $\delta 3.10\left(\mathrm{~m}, 8 \mathrm{H}, \mathrm{N}-\mathrm{CH}_{2}\right), 1.54\left(\mathrm{~m}, 8 \mathrm{H}, \mathrm{CH}_{2}\right), 1.37\left(\mathrm{~m}, 8 \mathrm{H}, \mathrm{CH}_{2}\right), 0.95\left(\mathrm{t}, 12 \mathrm{H}, \mathrm{CH}_{3}\right)$ (Figure S9a). ${ }^{19} \mathrm{~F}$ NMR (500 MHz, $\mathrm{CDCl}_{3}, \mathrm{C}_{6} \mathrm{~F}_{6}$ as internal reference): $\delta-79.91$ (s, 6F, $\mathrm{CF}_{3}$ ) (Figure S9b).

Scheme S1. Synthesis of ZnTPPS and ZnTPPS ${ }^{4-} 4 \mathrm{TBA}^{+}$.

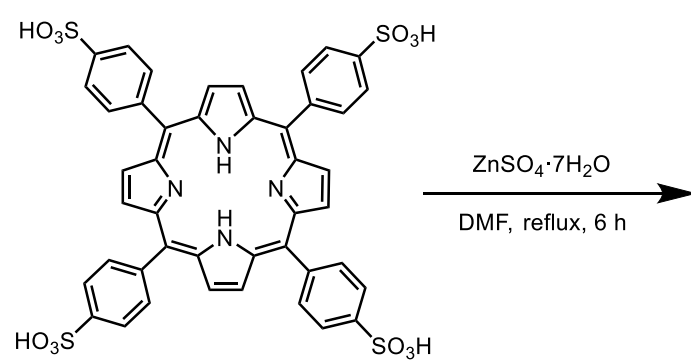

$\mathrm{H}_{2}$ TPPS

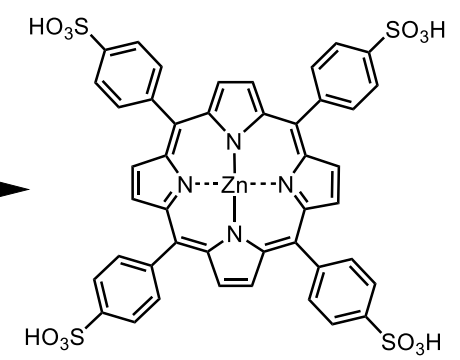

ZnTPPS $(73 \%$ yield $)$

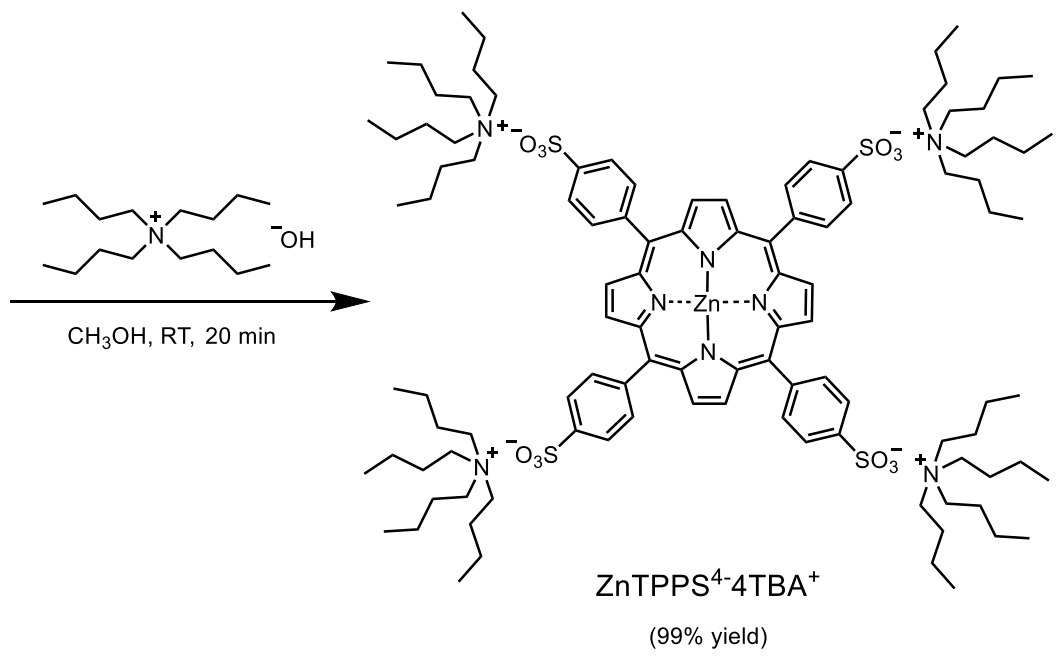


Scheme S2. Synthesis of $\mathrm{H}_{2} \mathrm{TF}_{4} \mathrm{PP}$ and $\mathrm{ZnTF}_{4} \mathrm{PP}$.

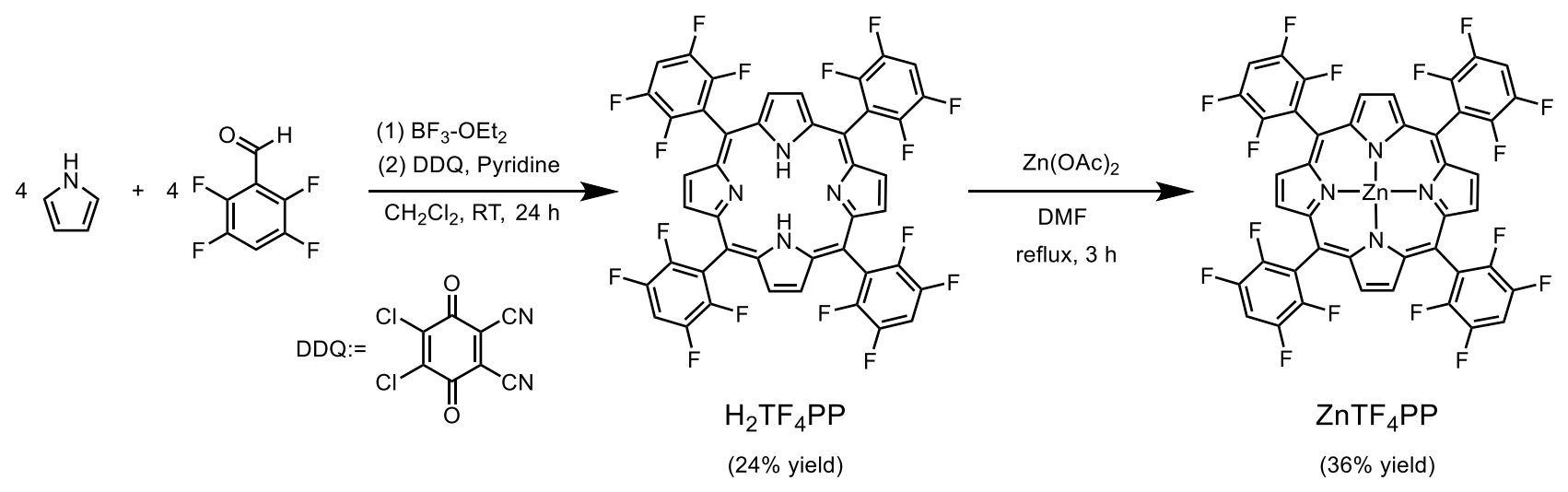

Scheme S3. Synthesis of $\mathrm{H}_{2} \mathrm{TF}_{2} \mathrm{PP}$ and $\mathrm{ZnTF}_{2} \mathrm{PP}$.

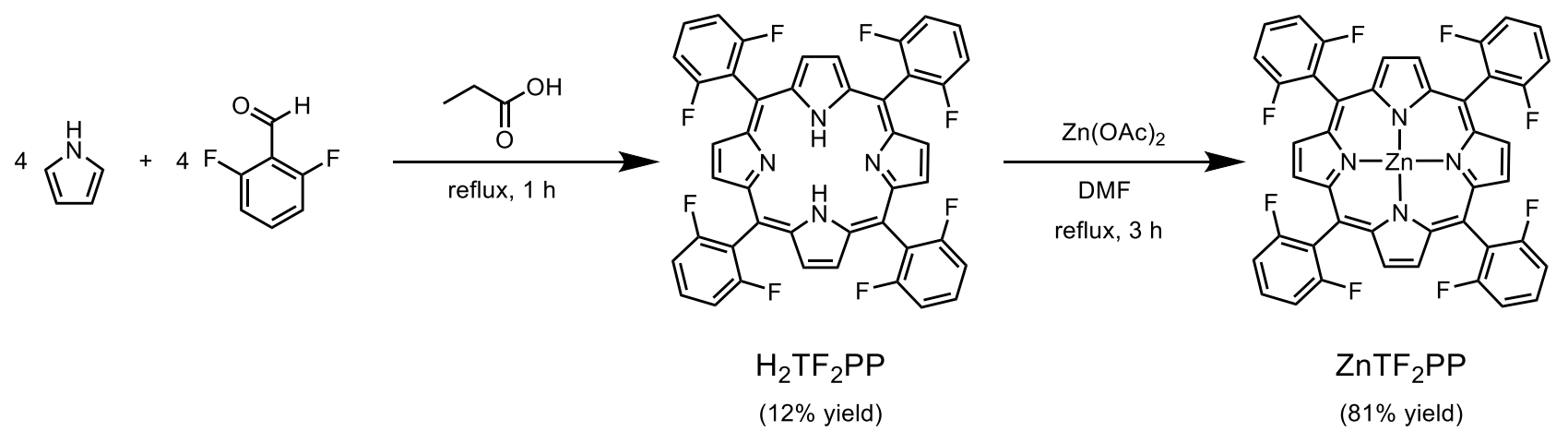

Scheme S4. Synthesis of TBA TFSI ${ }^{+}$.

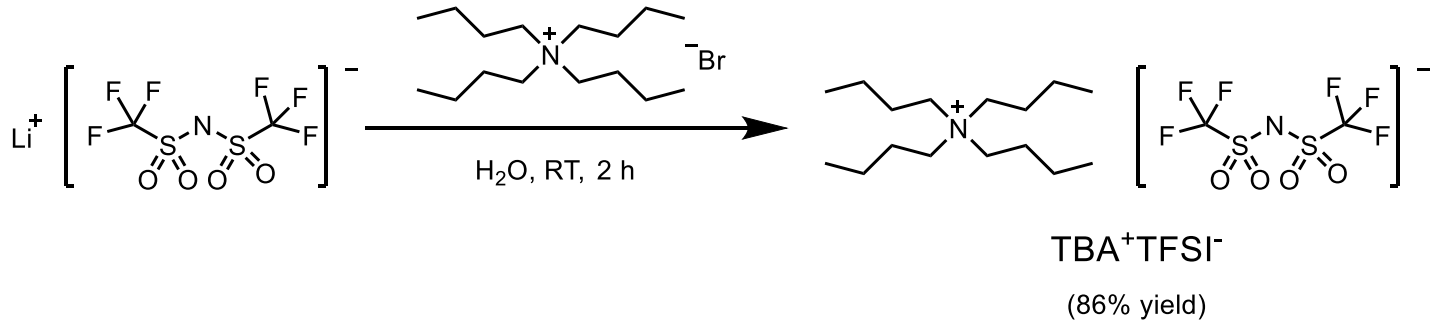


(a)

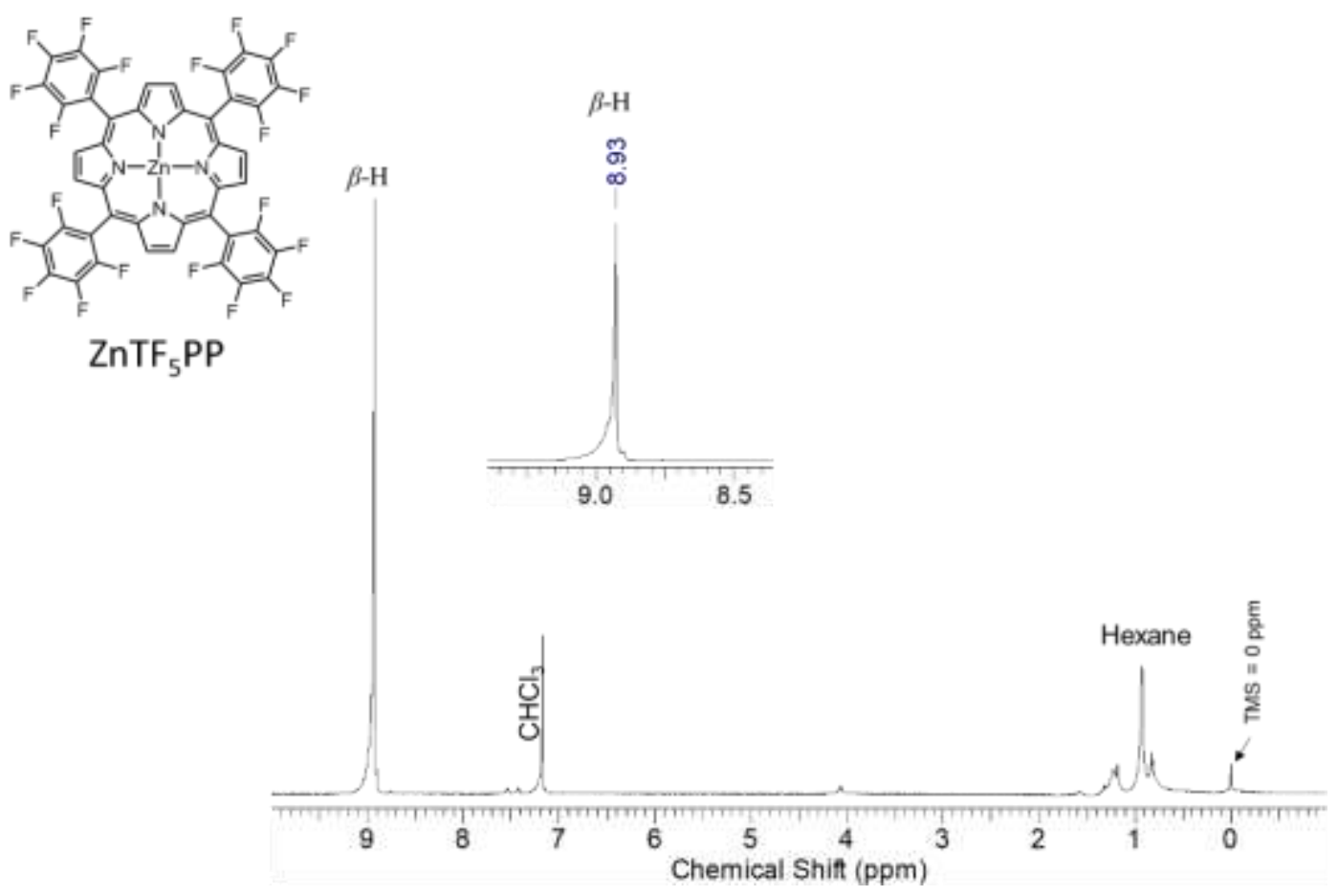

(b)

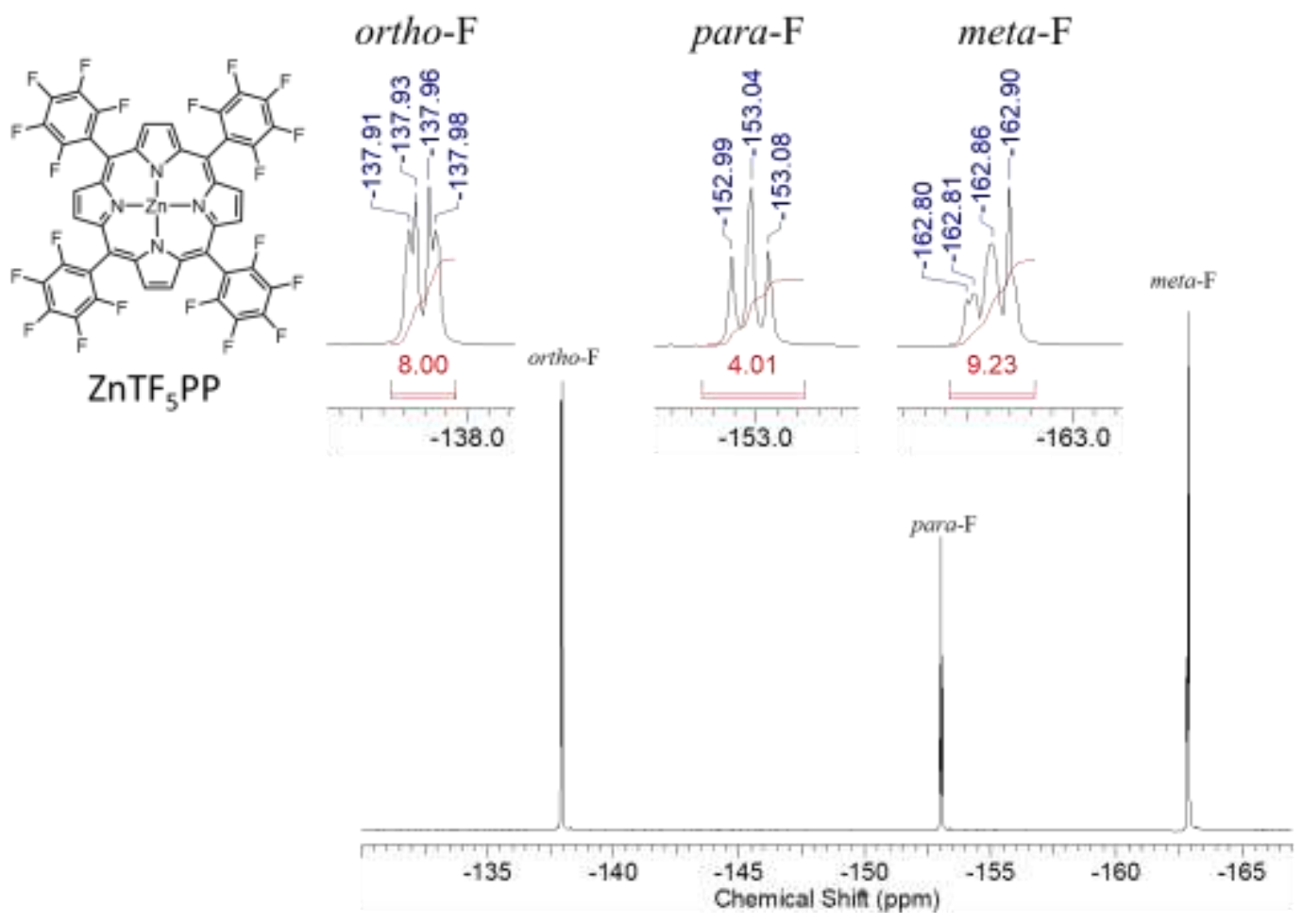

Figure S1. (a) ${ }^{1} \mathrm{H}$ and (b) ${ }^{19} \mathrm{~F}$ NMR spectra of $\mathrm{ZnTF}_{5} \mathrm{PP}$ in $\mathrm{CDCl}_{3}(500 \mathrm{MHz}, 293 \mathrm{~K})$. 
(a)

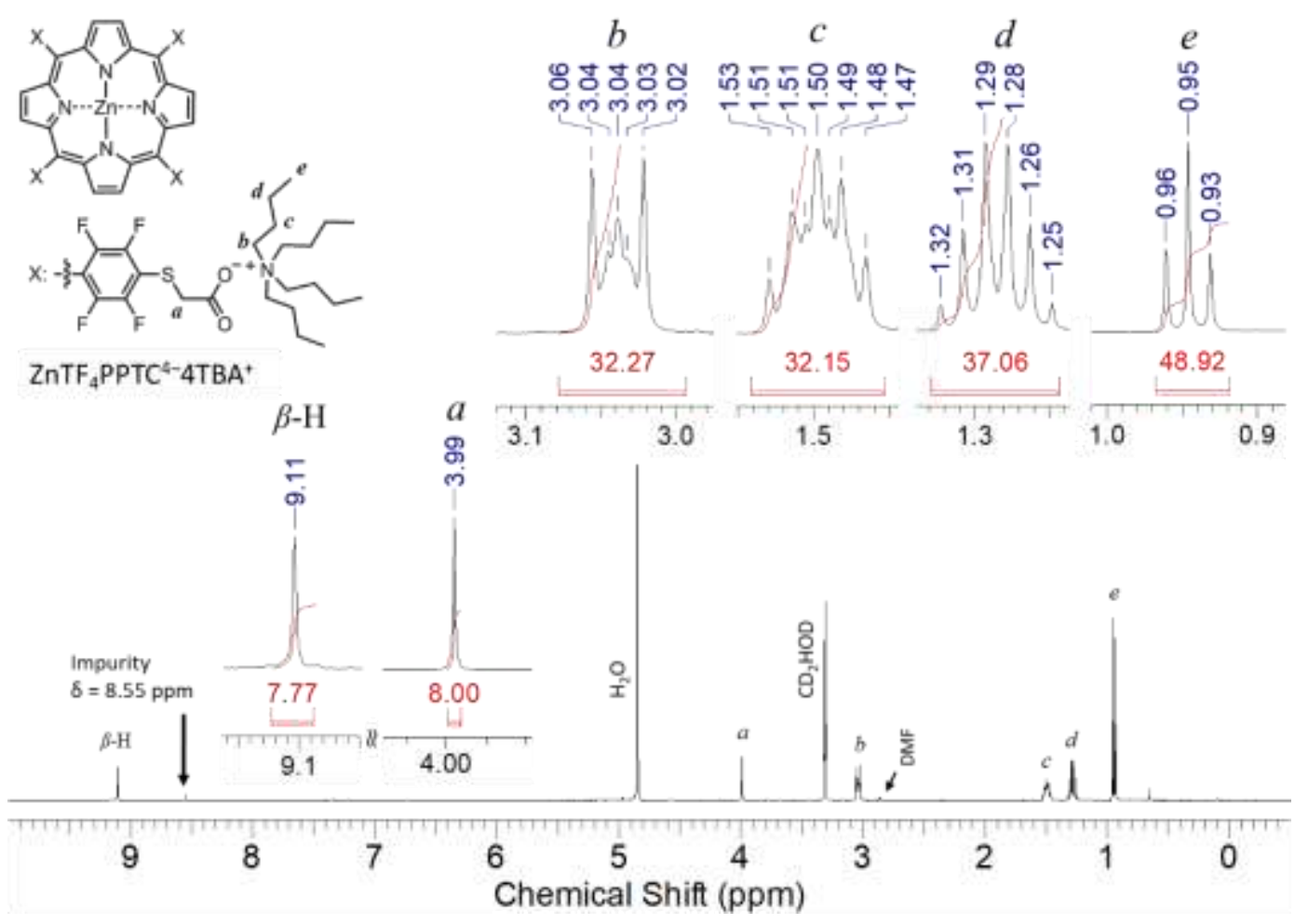

(b)

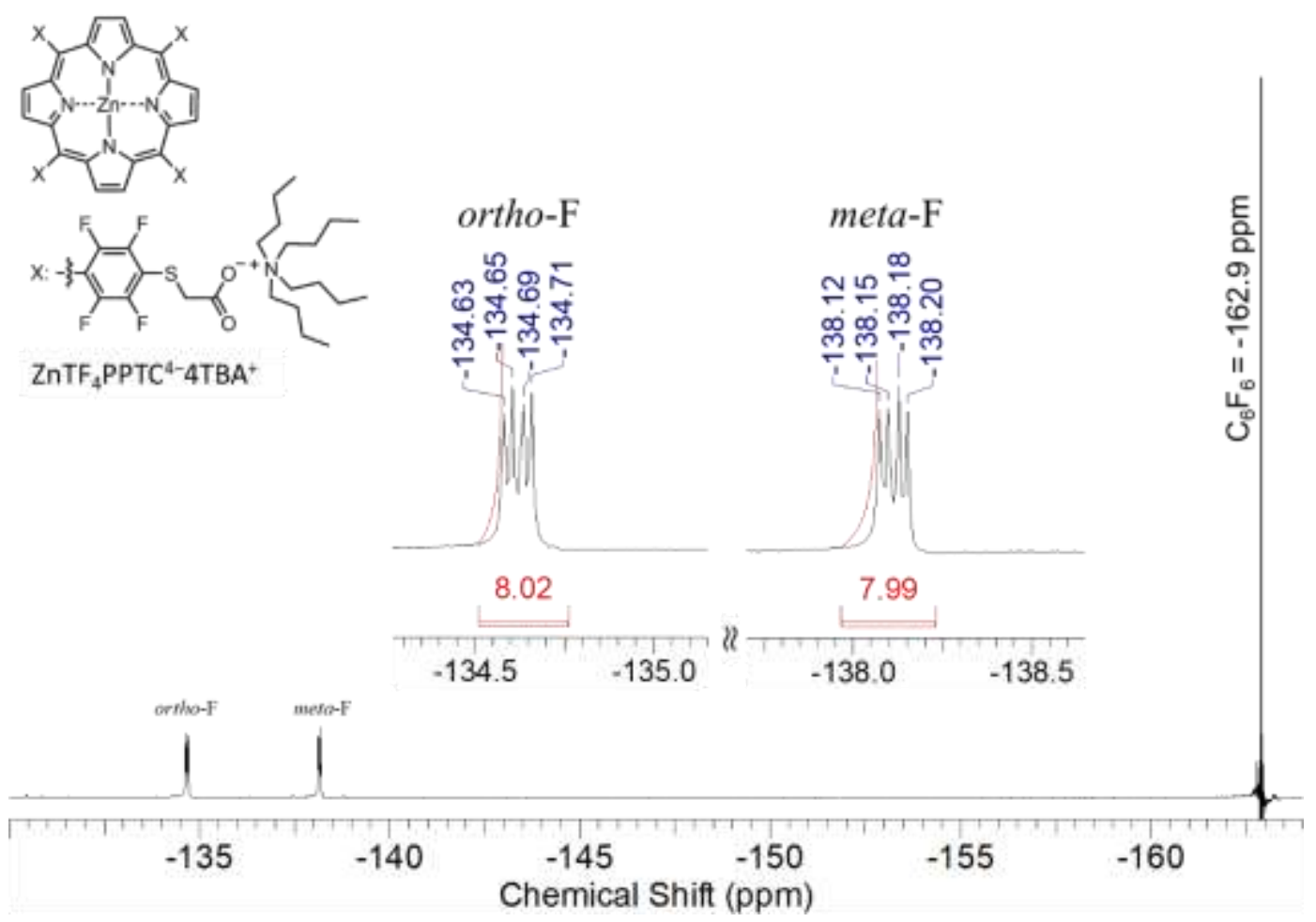

Figure S2. (a) ${ }^{1} \mathrm{H}$ and (b) ${ }^{19} \mathrm{~F}$ NMR spectra of $\mathrm{ZnTF}_{4} \mathrm{PPTC}^{4-} 4 \mathrm{TBA}^{+}$in $\mathrm{CD}_{3} \mathrm{OD}(500 \mathrm{MHz}, 293 \mathrm{~K})$. 


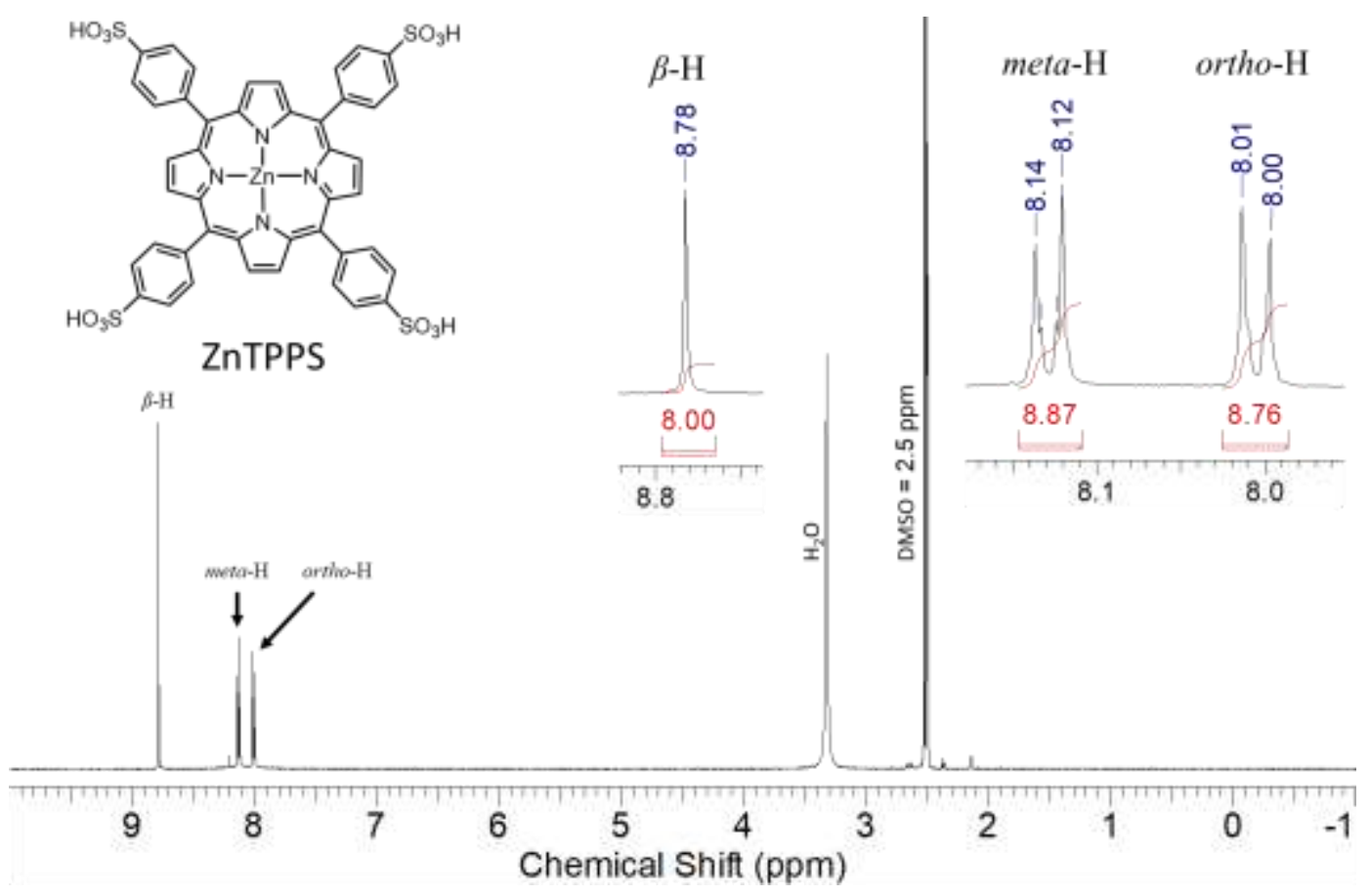

Figure S3. ${ }^{1} \mathrm{H}$ NMR spectrum of ZnTPPS in DMSO- $d_{6}(500 \mathrm{MHz}, 293 \mathrm{~K})$.

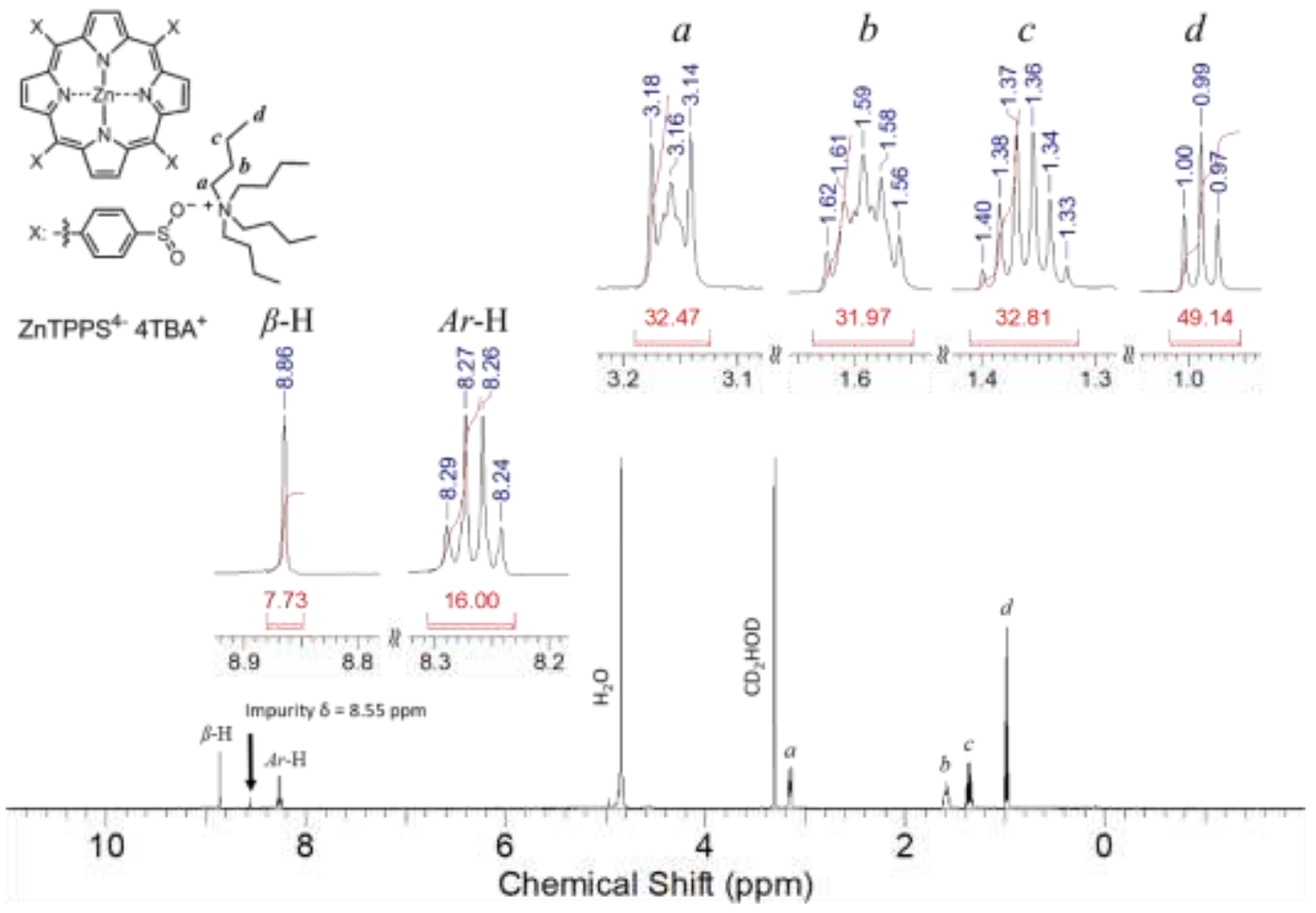

Figure S4. ${ }^{1} \mathrm{H}$ NMR spectrum of $\mathrm{ZnTPPS}^{4-}{ }^{4 \mathrm{TBA}^{+}}$in $\mathrm{CD}_{3} \mathrm{OD}(500 \mathrm{MHz}, 293 \mathrm{~K})$. 
(a)

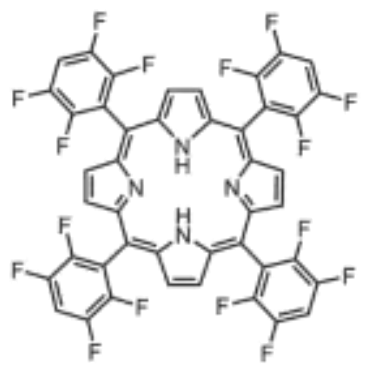

$\mathrm{H}_{2} \mathrm{TF}_{4} \mathrm{PP}$

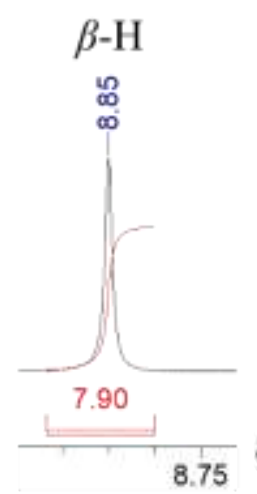

para-H

N-H

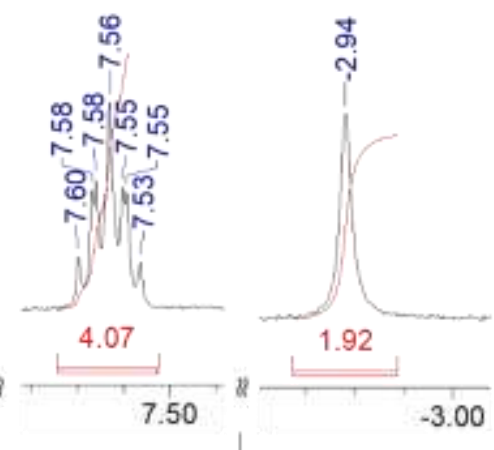

-
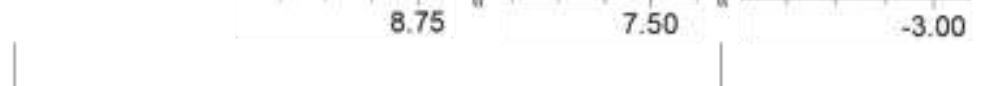

(b)

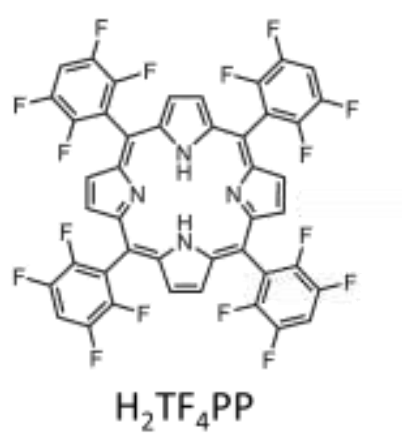

meta-F

ortho-F

趈

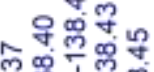

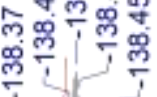

र产
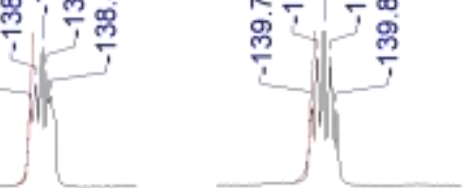

8.03
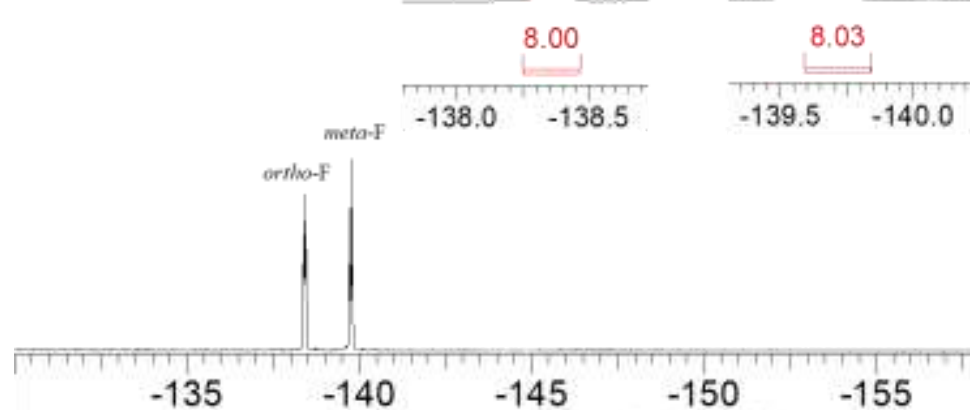

Chemical Shift (ppm)

Figure S5. (a) ${ }^{1} \mathrm{H}$ and (b) ${ }^{19} \mathrm{~F}$ NMR spectra of $\mathrm{H}_{2} \mathrm{TF}_{4} \mathrm{PP}$ in $\mathrm{CDCl}_{3}(500 \mathrm{MHz}, 293 \mathrm{~K})$. 
(a)

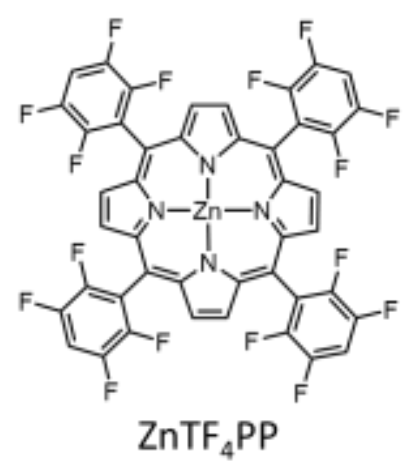
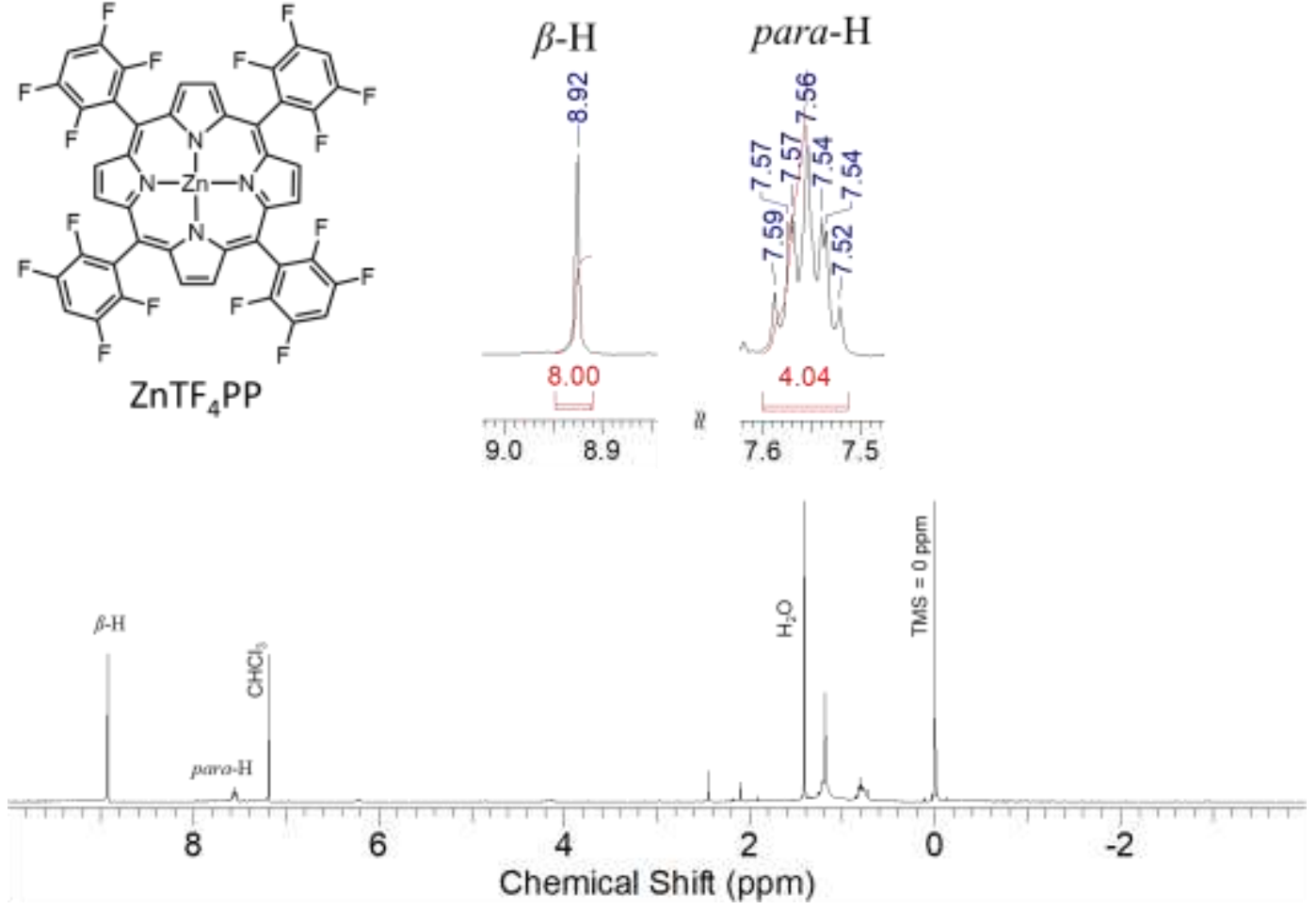

(b)
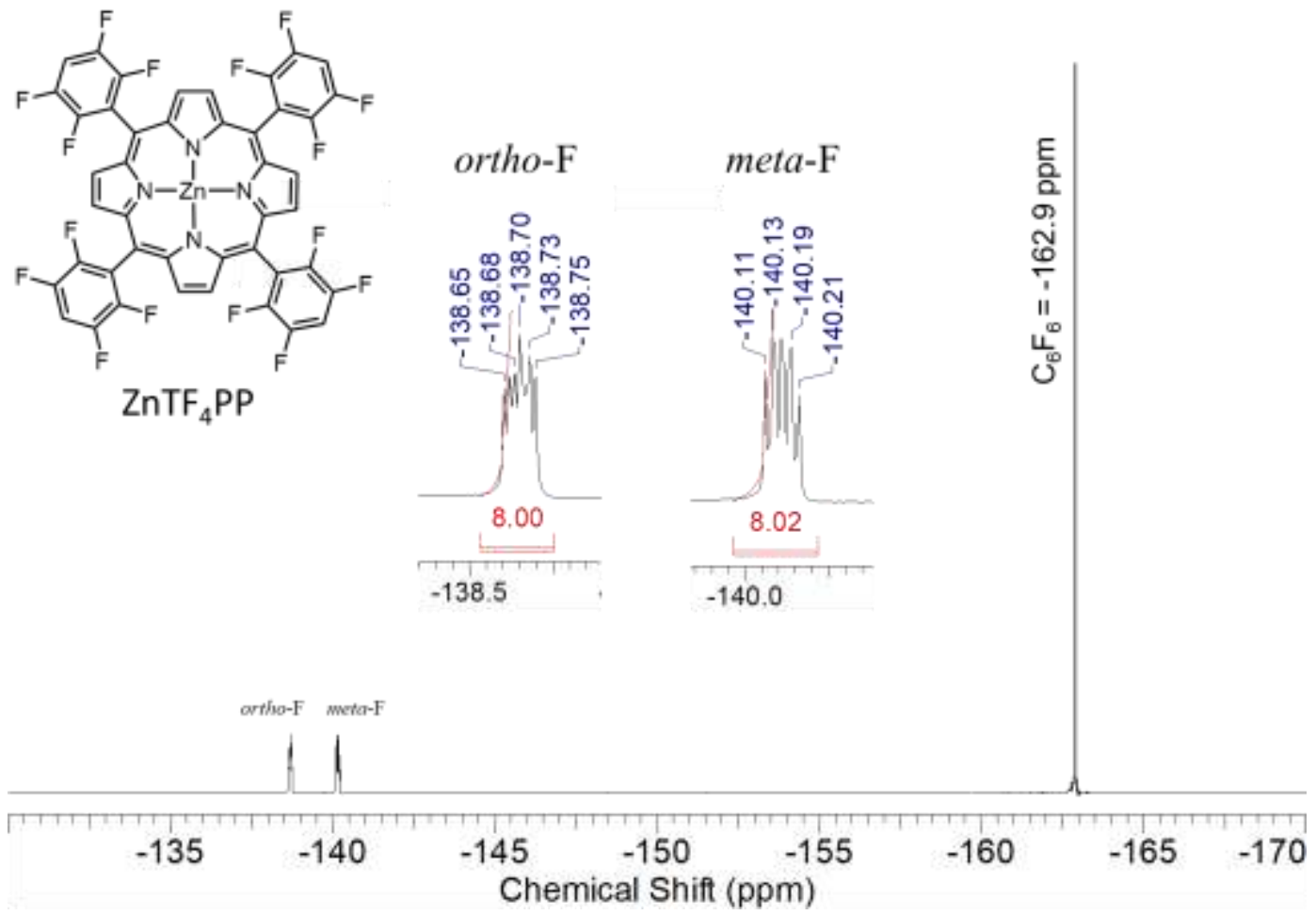

Figure S6. (a) ${ }^{1} \mathrm{H}$ and (b) ${ }^{19} \mathrm{~F}$ NMR spectra of $\mathrm{ZnTF}_{4} \mathrm{PP}$ in $\mathrm{CDCl}_{3}(500 \mathrm{MHz}, 293 \mathrm{~K})$. 
(a)

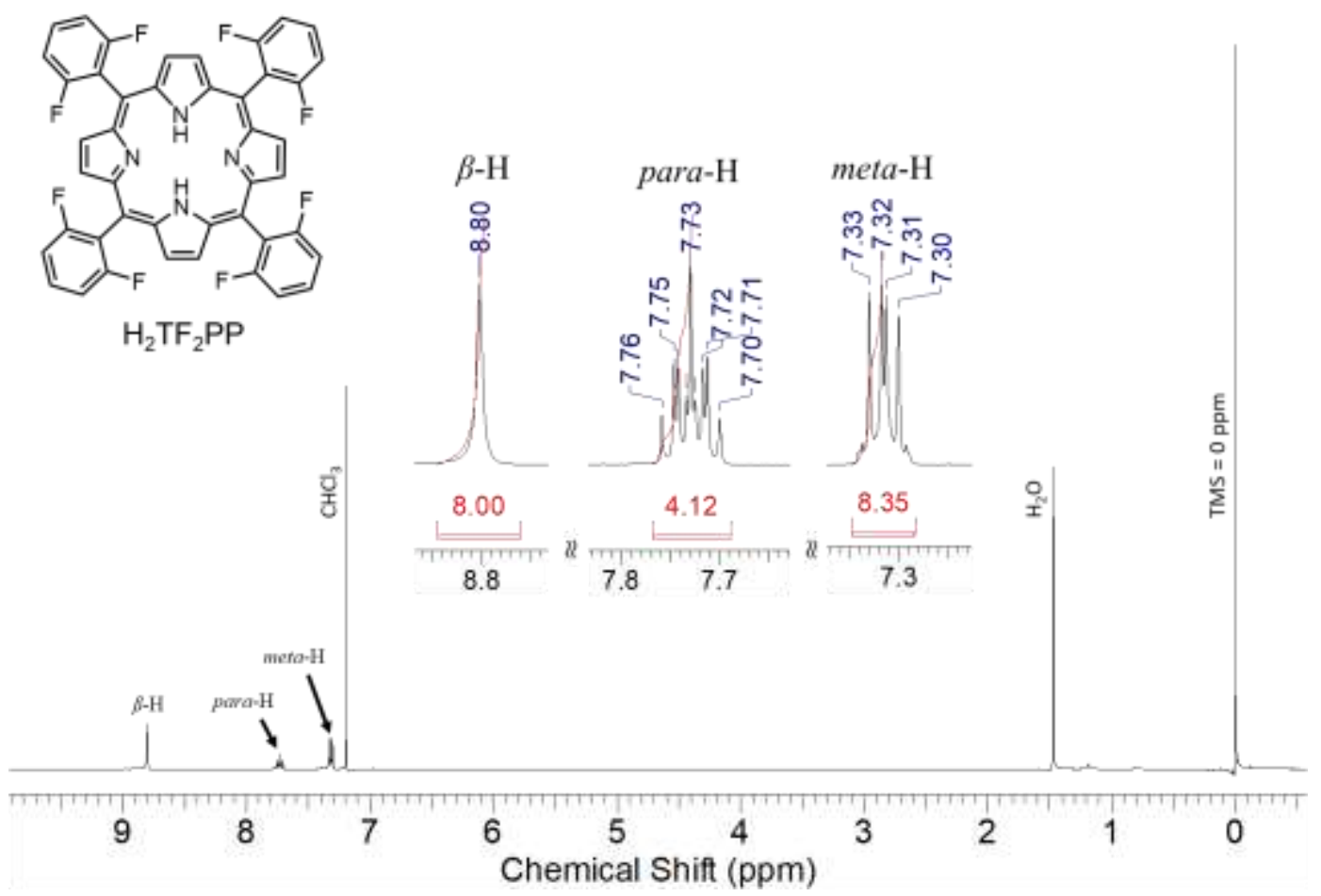

(b)

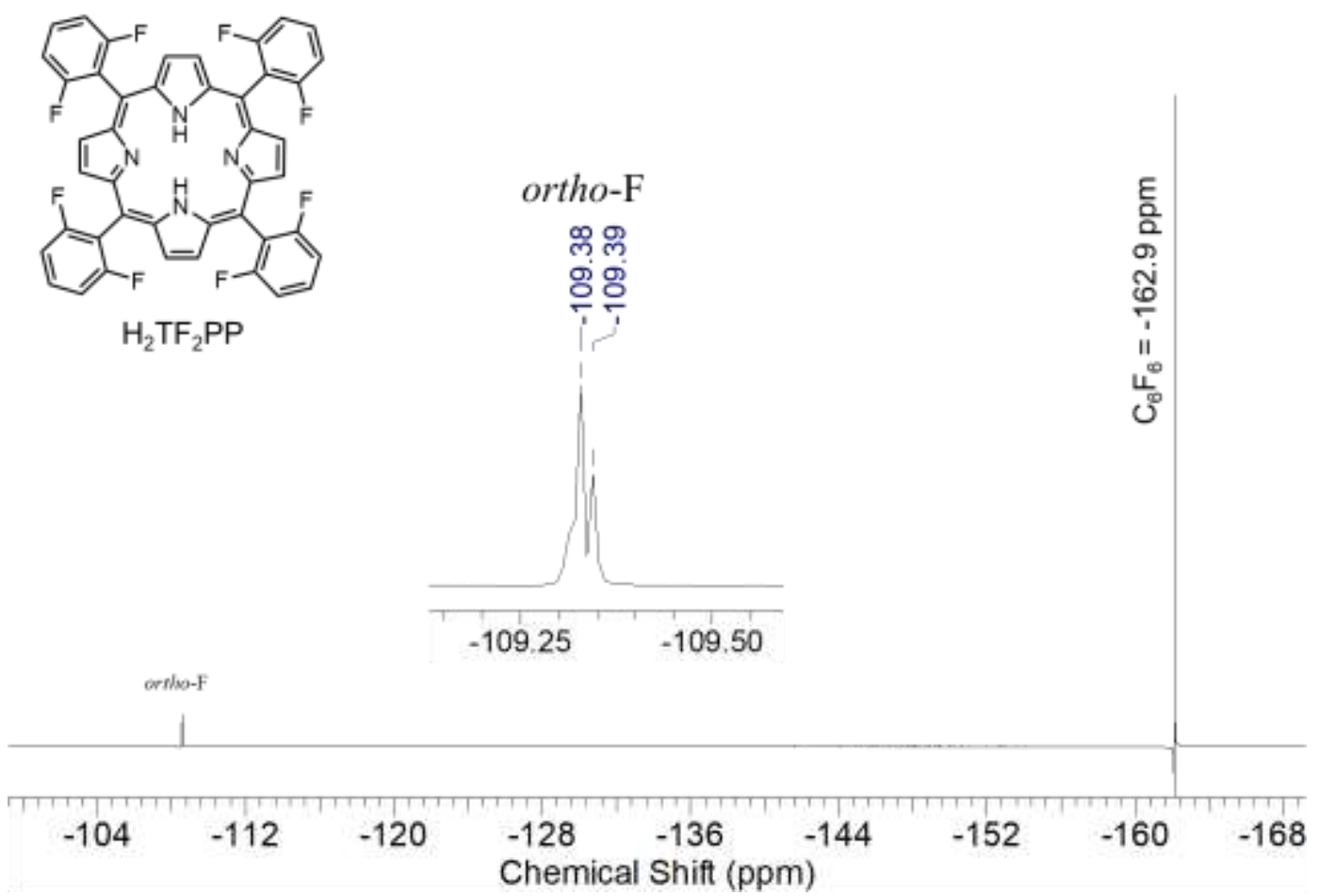

Figure S7. (a) ${ }^{1} \mathrm{H}$ and (b) ${ }^{19} \mathrm{~F}$ NMR spectra of $\mathrm{H}_{2} \mathrm{TF}_{2} \mathrm{PP}$ in $\mathrm{CDCl}_{3}(500 \mathrm{MHz}, 293 \mathrm{~K})$. 
(a)

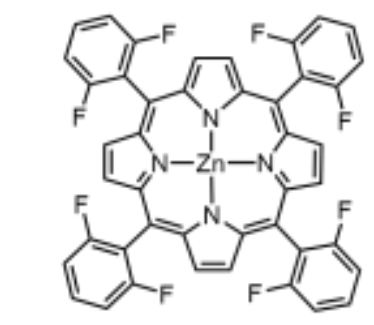

$\beta-\mathrm{H} \quad$ para- $\mathrm{H} \quad$ meta- $\mathrm{H}$

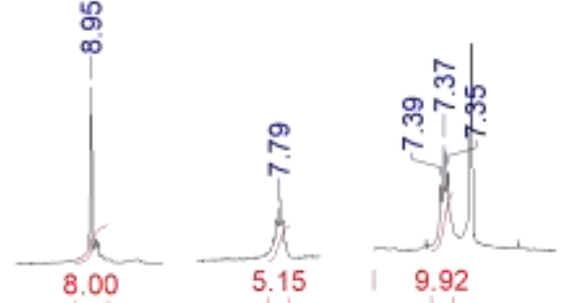

$\mathrm{ZnTF}_{2} \mathrm{PP}$

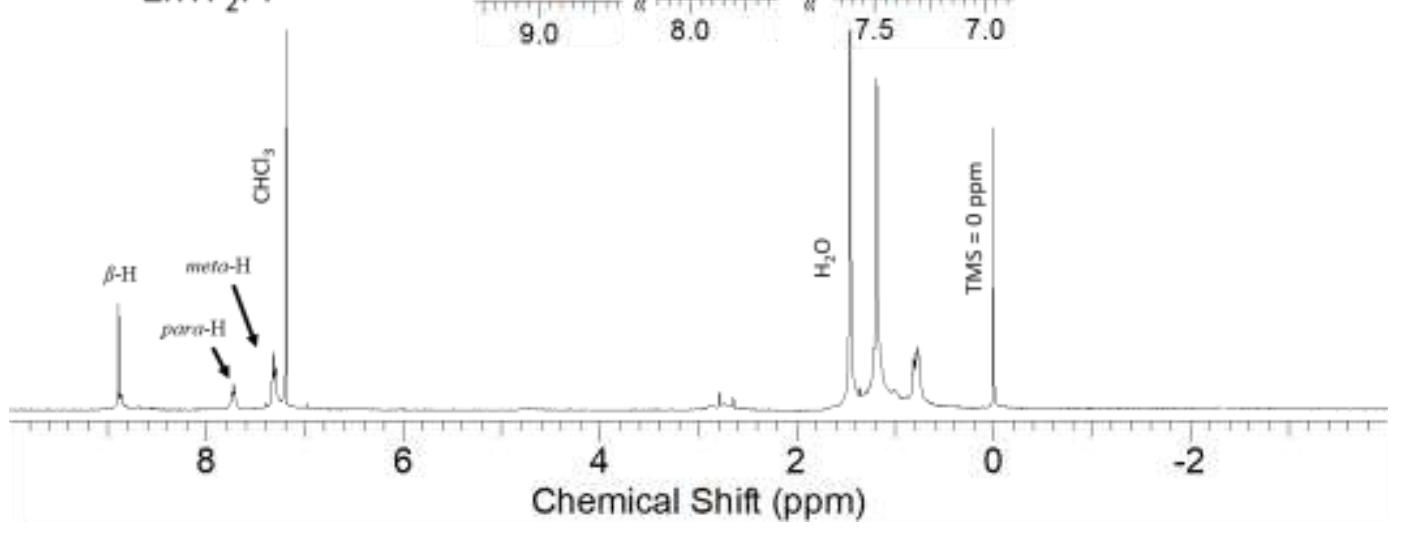

(b)
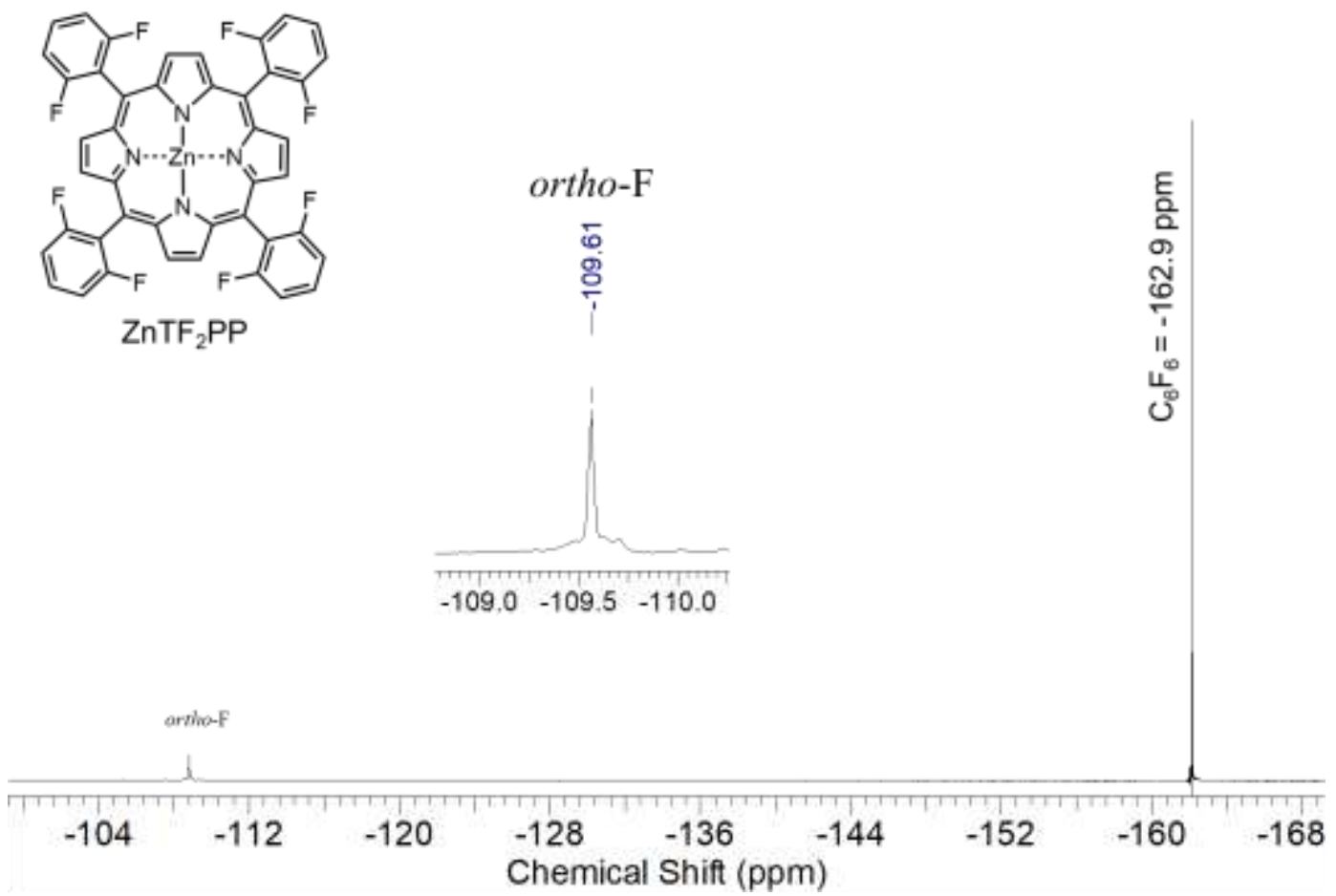

Figure S8. (a) ${ }^{1} \mathrm{H}$ and (b) ${ }^{19} \mathrm{~F}$ NMR spectra of $\mathrm{ZnTF}_{2} \mathrm{PP}$ in $\mathrm{CDCl}_{3}(500 \mathrm{MHz}, 293 \mathrm{~K})$. 
(a)

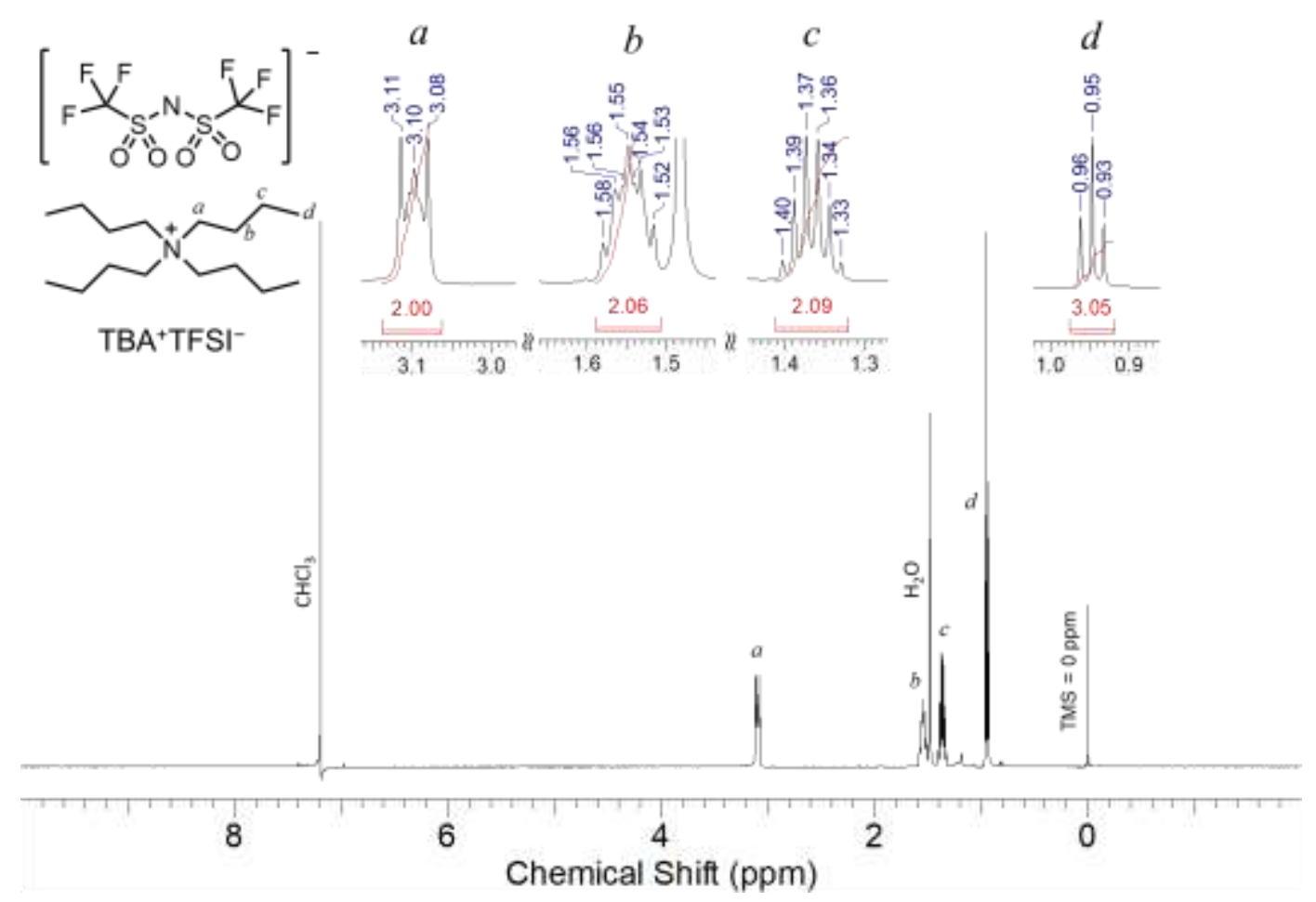

(b)<smiles>O=S(=O)(NS(=O)(=O)C(F)(F)F)C(F)(F)F</smiles>
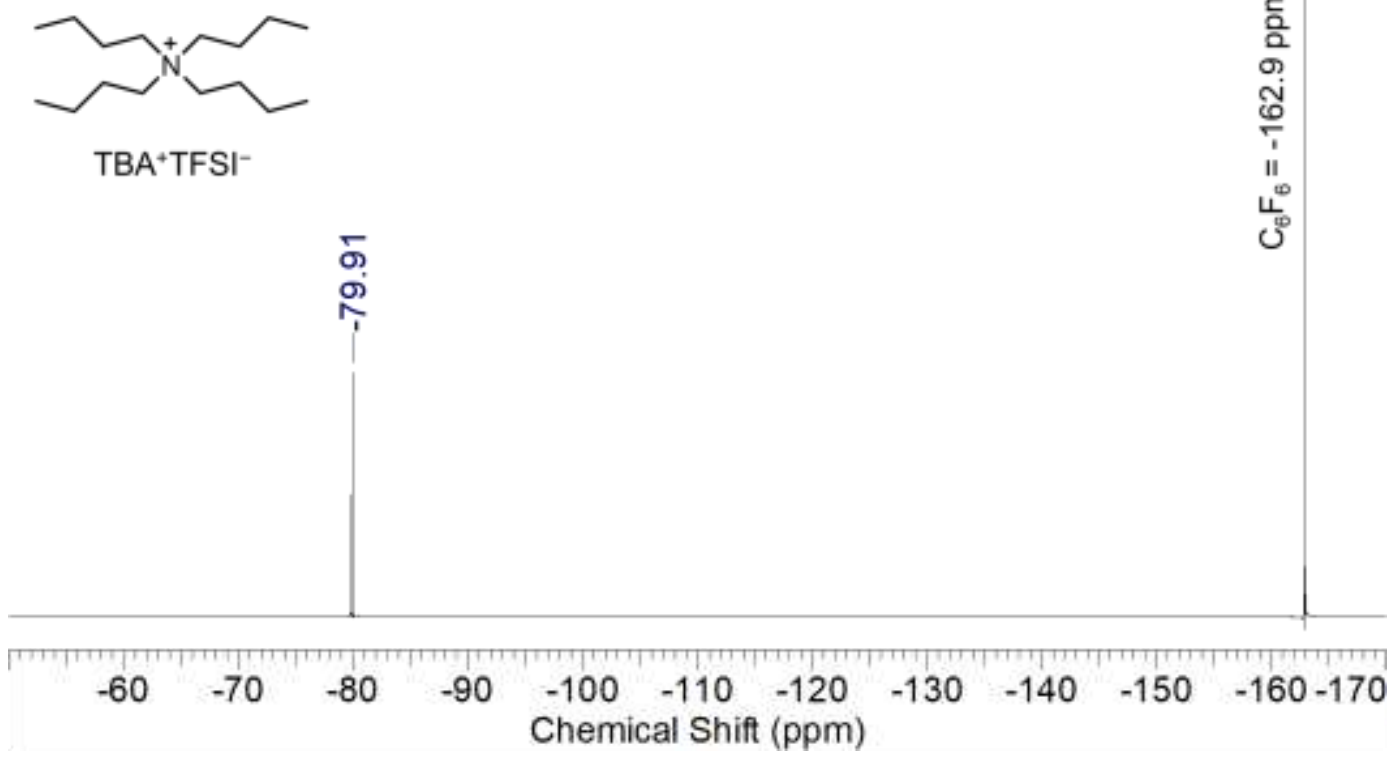

Figure S9. (a) ${ }^{1} \mathrm{H}$ and (b) ${ }^{19} \mathrm{~F}$ NMR spectra of $\mathrm{TBA}^{+} \mathrm{TFSI}^{-}$in $\mathrm{CDCl}_{3}(500 \mathrm{MHz}, 293 \mathrm{~K})$. 


\section{CV and DPV curves of $\mathrm{H}_{2} \mathrm{TF}_{2} \mathrm{PP}$ and $\mathrm{H}_{2} \mathrm{TF}_{4} \mathrm{PP}$}

Figure S10 shows $\mathrm{CV}$ and DPV curves of $\mathrm{H}_{2} \mathrm{TF}_{2} \mathrm{PP}$ and $\mathrm{H}_{2} \mathrm{TF}_{4} \mathrm{PP}$. The first one-electron oxidation potentials $\left(E_{\mathrm{ox}}\right.$ vs. ferrocene/ferrocenium $\left.\left(\mathrm{Fc} / \mathrm{Fc}^{+}\right)\right)$are also shown in the figure. The $E_{\mathrm{ox}}$ is increased with increasing the number of electronegative fluorine substituents, and decreased by zinc metalation (Figure 4).

(a)

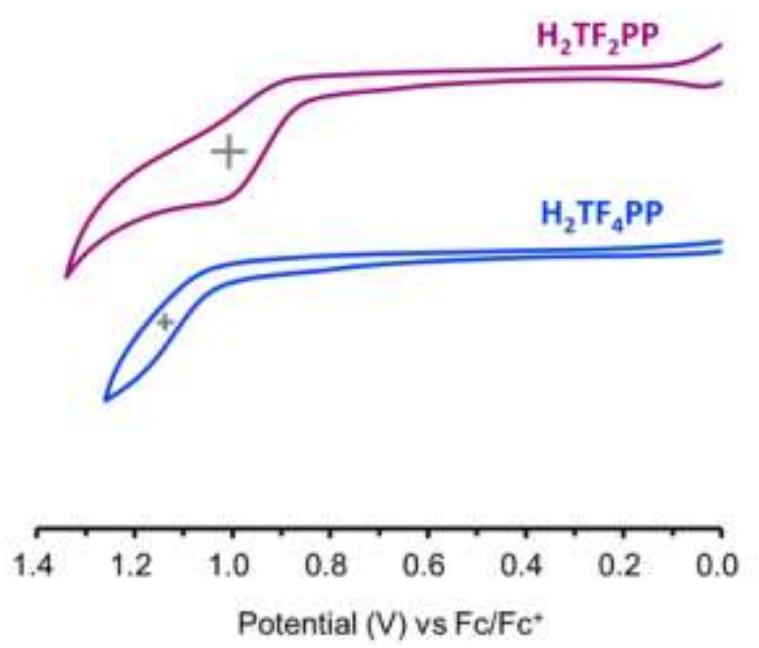

(b)

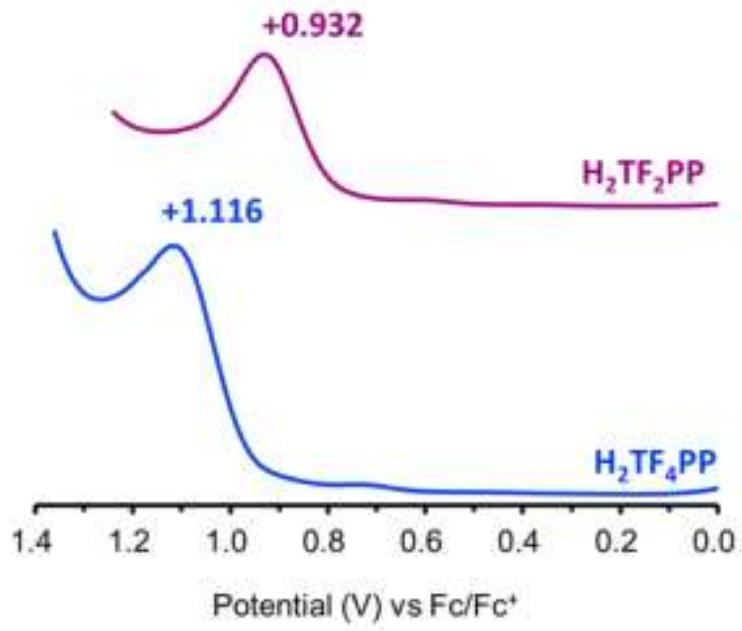

Figure S10. (a) CV and (b) DPV curves of $\mathrm{H}_{2} \mathrm{TF}_{2} \mathrm{PP}$ and $\mathrm{H}_{2} \mathrm{TF}_{4} \mathrm{PP}$ in DMF with electrolyte of $0.05 \mathrm{M}$ TBA $^{+}$TFSI $^{-}$. The scan rates are $0.1 \mathrm{Vs}^{-1}$ for $\mathrm{CV}$ and $4 \mathrm{mVs}^{-1}$ for DPV. The first one-electron oxidation potentials $\left(E_{\mathrm{ox}} \mathrm{vs} . \mathrm{Fc} / \mathrm{Fc}^{+}\right)$determined from the DPV curves are also shown.

\section{X-ray structure analysis of $\mathrm{H}_{2} \mathrm{TF}_{4} \mathrm{PP}$ and $\left(\mathrm{H}_{2} \mathrm{TF}_{4} \mathrm{PP}\right)_{3}\left(\mathrm{Li}^{+} @ \mathrm{C}_{60} \mathrm{TFSI}^{-}\right)_{2}$}

Crystals of $\mathrm{H}_{2} \mathrm{TF}_{4} \mathrm{PP}$ and 3:2 co-crystals of $\mathrm{H}_{2} \mathrm{TF}_{4} \mathrm{PP}$ with $\mathrm{Li}^{+} @ \mathrm{C}_{60} \mathrm{TFSI}^{-}$were obtained by vapor diffusion method. The crystal structures were solved and refined by using SIR and SHELXL software. The results are summarized in Table S1. ORTEP drawings are shown in Figures S11 and S12. 
Table S1. Crystallographic data of $\mathrm{H}_{2} \mathrm{TF}_{4} \mathrm{PP}$ and $\left(\mathrm{H}_{2} \mathrm{TF}_{4} \mathrm{PP}\right)_{3}\left(\mathrm{Li}^{+} @ \mathrm{C}_{60} \mathrm{TFSI}^{-}\right)_{2}$.

\begin{tabular}{|c|c|c|}
\hline compound & $\mathrm{H}_{2} \mathrm{TF}_{4} \mathrm{PP}$ & $\left(\mathrm{H}_{2} \mathrm{TF}_{4} \mathrm{PP}\right)_{3}\left(\mathrm{Li}^{+} @ \mathrm{C}_{60} \mathrm{TFSI}^{-}\right)_{2}$. \\
\hline formula & $\mathrm{C}_{44} \mathrm{H}_{14} \mathrm{~N}_{4} \mathrm{~F}_{16}$ & $3\left(\mathrm{C}_{44} \mathrm{H}_{14} \mathrm{~N}_{4} \mathrm{~F}_{16}\right) \cdot 2\left(\mathrm{LiC}_{60}\right) \cdot 2\left(\mathrm{~N}\left(\mathrm{SO}_{2} \mathrm{CF}_{3}\right)_{2}\right)$ \\
\hline formula weight & 902.59 & 2361.58 \\
\hline crystal size $(\mathrm{mm})$ & $0.20 \times 0.20 \times 0.09$ & $0.19 \times 0.13 \times 0.01$ \\
\hline temperature & $90 \mathrm{~K}$ & $90 \mathrm{~K}$ \\
\hline X-ray wavelength & $0.4139 \AA$ & $0.4139 \AA$ \\
\hline crystal system & trigonal & triclinic \\
\hline space group & $R \overline{3}$ & $P \overline{1}$ \\
\hline \multirow[t]{7}{*}{ unit cell parameters } & $a=19.592(4) \AA$ & $a=14.880(9) \AA$ \\
\hline & $c=24.526(2) \AA$ & $b=17.993(6) \AA$ \\
\hline & $V=8153(3) \AA^{3}$ & $c=20.408(7) \AA$ \\
\hline & & $\alpha=108.06(4)^{\circ}$ \\
\hline & & $\beta=109.56(4)^{\circ}$ \\
\hline & & $\gamma=101.75(4)^{\circ}$ \\
\hline & & $V=4597(4) \AA^{3}$ \\
\hline$Z$ & 9 & 2 \\
\hline $\begin{array}{l}\text { No. of measured } \\
\text { reflections }\end{array}$ & $44,104(d>0.85 \AA)$ & $48,511(d>0.97 \AA)$ \\
\hline $\begin{array}{l}\text { No. of independent } \\
\text { reflections }\end{array}$ & $3,095(d>0.85 \AA)$ & $10,430(d>0.97 \AA)$ \\
\hline$R_{\text {sigma }}$ & 0.0149 & 0.1212 \\
\hline$R_{\text {int }}$ & 0.0348 & 0.1541 \\
\hline No. of parameters & 317 & 1401 \\
\hline$R 1$ (all data) & 0.0473 & 0.1276 \\
\hline$w R$ (all data) & 0.1099 & 0.2518 \\
\hline GOF (all data) & 1.065 & 1.028 \\
\hline$R 1\left(>4 \sigma_{\mathrm{F}}\right)$ & 0.0453 & 0.0900 \\
\hline$w R\left(>4 \sigma_{\mathrm{F}}\right)$ & 0.1086 & 0.2236 \\
\hline $\operatorname{GOF}\left(>4 \sigma_{\mathrm{F}}\right)$ & 1.065 & 1.029 \\
\hline CCDC No. & 2025474 & 2025475 \\
\hline
\end{tabular}




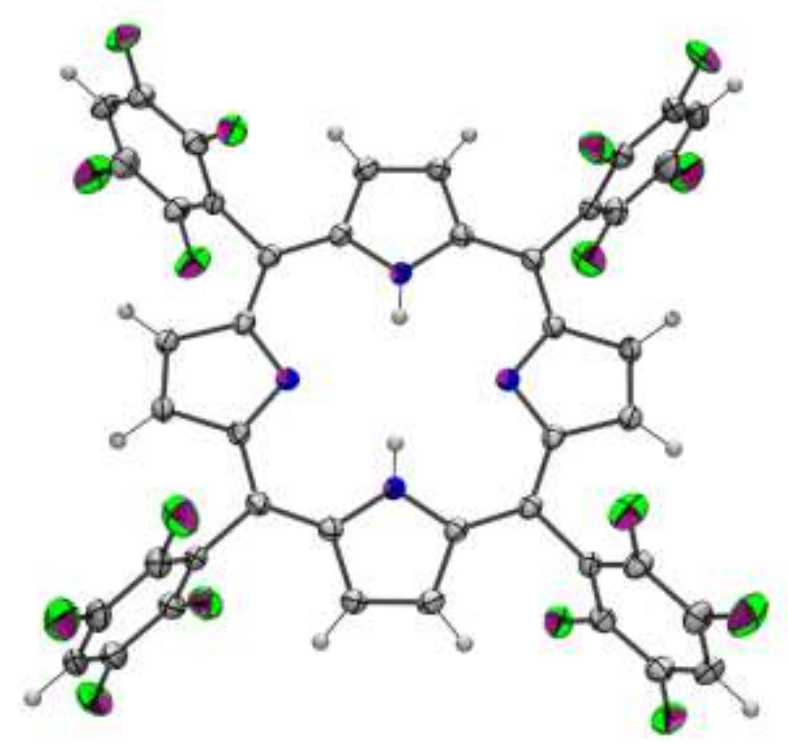

Figure S11. ORTEP drawing of $\mathrm{H}_{2} \mathrm{TF}_{4} \mathrm{PP}$ with atomic displacement ellipsoids at 50\% probability level (gray: carbon, blue: nitrogen, green: fluorine; $\mathrm{H}$ atoms with arbitrary radii).

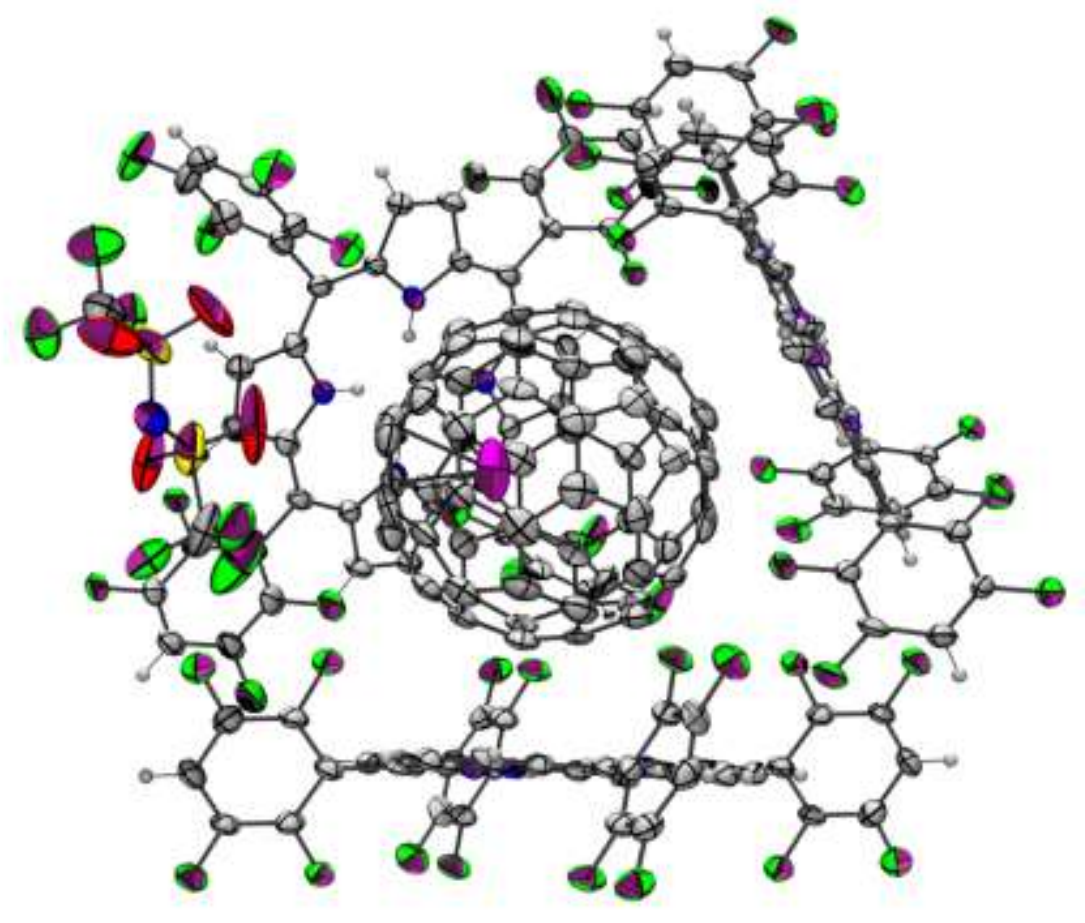

Figure S12. ORTEP drawing of $\left(\mathrm{H}_{2} \mathrm{TF}_{4} \mathrm{PP}\right)_{3}\left(\mathrm{Li}^{+} @ \mathrm{C}_{60} \mathrm{TFSI}^{-}\right)_{2}$ with atomic displacement ellipsoids at 50\% probability level (magenta: lithium, gray: carbon, blue: nitrogen, red: oxygen, green: fluorine, yellow: sulfur; $\mathrm{H}$ atoms with arbitrary radii). Disordered structures of TFSI ${ }^{-}$are omitted for clarity. 


\section{References}

(1) Das, S. K.; Song, B.; Mahler, A.; Nesterov, V. N.; Wilson, A. K.; Ito, O.; D'Souza, F. Electron Transfer Studies of High Potential Zinc Porphyrin-Fullerene Supramolecular Dyads. J. Phys. Chem. C, 2014, 118, 3994-4006.

(2) Lourenço, L. M. O.; Resende, J.; Iglesias, B. A.; Castro, K.; Nakagaki, S.; Lima, M. J.; da Cunha, A. F.; Neves, M. G. P. M. S.; Cavaleiro, J. A. S.; Tomé, J. P. C. Synthesis, Characterization and Electrochemical Properties of meso-Thiocarboxylate-Substituted Porphyrin Derivatives. J. Porphyrins Phthalocyanines, 2014, $18,967-974$.

(3) Saha, T. K.; Yoshikawa, Y.; Sakurai, H. A [meso-Tetrakis(4-Sulfonatophenyl)Porphyrinato]Zinc(II) Complex as an Oral Therapeutic for the Treatment of Type 2 Diabetic KKA ${ }^{\mathrm{y}}$ Mice. ChemMedChem., 2007, 2, $218-225$.

(4) Huang, N.; Wang, K.; Drake, H.; Cai, P.; Pang, J.; Li, J.; Che, S.; Huang, L.; Wang, Q.; Zhou, H.-C. Tailor-Made Pyrazolide-Based Metal-Organic Frameworks for Selective Catalysis. J. Am. Chem. Soc., 2018, 140, 6383-6390.

(5) Adler, A. D.; Longo, F. R.; Kampas, F.; Kim, J. On the Preparation of Metalloporphyrins. J. Inorg. Nucl. Chem., 1970, 32, 2443-2445.

(6) Adler, A. D.; Longo, F. R.; Finarelli, J. D.; Goldmacher, J.; Assour, J.; Korsakoff, L. A Simplified Synthesis for meso-Tetraphenylporphine. J. Org. Chem., 1967, 32, 476.

(7) Sun, J.; MacFarlane, D. R.; Forsyth, M. Synthesis and Properties of Ambient Temperature Molten Salts Based on the Quaternary Ammonium Ion. Ionic, 1997, 3, 356-362. 